\title{
Measurement report: Diurnal and temporal variations of sugar compounds in suburban aerosols from the northern vicinity of Beijing, China - an influence of biogenic and anthropogenic sources
}

\author{
Santosh Kumar Verma ${ }^{1,2}$, Kimitaka Kawamura ${ }^{1,3}$, Fei Yang ${ }^{1,4}$, Pingqing Fu ${ }^{1,5}$, Yugo Kanaya ${ }^{6}$, and Zifa Wang ${ }^{7}$ \\ ${ }^{1}$ Institute of Low Temperature Science, Hokkaido University, Sapporo 060-0819, Japan \\ ${ }^{2}$ State Forensic Science Laboratory, Home Department, Government of Chhattisgarh, Raipur 491001, India \\ ${ }^{3}$ Chubu Institute for Advanced Studies, Chubu University, Kasugai 487-8501, Japan \\ ${ }^{4}$ Graduate School of Environmental Science, Hokkaido University, Sapporo 060-0810, Japan \\ ${ }^{5}$ Institute of Surface-Earth System Science, Tianjin University, Tianjin 300072, China \\ ${ }^{6}$ Research Institute for Global Change, Japan Agency for Marine-Earth Science and Technology, Yokohama, Japan \\ ${ }^{7}$ State Key Laboratory of Atmospheric Boundary Layer Physics and Atmospheric Chemistry, Institute of Atmospheric \\ Physics, Chinese Academy of Sciences, Beijing 100029, China
}

Correspondence: Kimitaka Kawamura (kkawamura@isc.chubu.ac.jp)

Received: 19 July 2020 - Discussion started: 19 August 2020

Revised: 14 February 2021 - Accepted: 15 February 2021 - Published: 30 March 2021

\begin{abstract}
Sugar compounds (SCs) are major water-soluble constituents in atmospheric aerosols. In this study, we investigated their molecular compositions and abundances in the northern receptor site (Mangshan) of Beijing, China, to better understand the contributions from biogenic and anthropogenic sources using a gas chromatography-mass spectrometry technique. The sampling site receives anthropogenic air mass transported from Beijing by southerly winds, while northerly winds transport relatively clean air mass from the forest areas. Day- and nighttime variations were analyzed for anhydrosugars, primary sugars, and sugar alcohols in autumn 2007. We found that biomass burning (BB) tracers were more abundant at nighttime than daytime, while other SCs showed different diurnal variations. Levoglucosan was found to be dominant sugar among the SCs observed, indicating an intense influence of local BB for cooking and space heating at the surroundings of the Mangshan site. The high levels of arabitol and mannitol in daytime suggest a significant contribution of locally emitted fungal spores and long-range-transported bioaerosols from the Beijing area. The plant emissions from Mangshan forest park significantly control the diurnal variations of glucose, fructose, and mannitol. The meteorological parameters (relative
\end{abstract}

humidity, temperature, and rainfall) significantly affect the concentrations and diurnal variations of SCs. Sucrose (pollen tracer) showed a clear diurnal variation, peaking in the daytime due to higher ambient temperature and wind speed, which influences the pollen release from the forest plants. We found the contribution of trehalose from soil dust in daytime, while microbial and fungal spores were responsible for nighttime. Anhydrosugar and primary sugars are prime carbon sources of the Mangshan aerosols. The high ratios of levoglucosan in organic carbon and water-soluble organic carbon at nighttime suggest a significant contribution of $\mathrm{BB}$ to organic aerosols at night. Levoglucosan / mannosan ratios demonstrate that low-temperature burning of hardwood is dominant in Mangshan. The positive matrix factorization analysis concluded that forest vegetation, fungal species, and local BB are the significant sources of SCs.

\section{Introduction}

Increased economic growth and massive consumption of fossil fuels from industries emit anthropogenic gases, aerosols, 
and biomass burning (BB) products and cause severe air pollution in East Asian countries (Lelieveld et al., 2015; Lin et al., 2014; Kawamura et al., 2013; Li et al., 2010; Sun et al., 2016). Globally, significant anthropogenic and carbonaceous aerosols are contributed by China (Cooke et al., 1999, Wang et al., 2007). Beijing is situated in the northern part of China, with a 20 million people and 5 million motor vehicles. Beijing is one of the largest polluted cities in East Asia; its air quality deteriorates seriously due to massive emissions of anthropogenic aerosols from vehicles and industries (Cao et al., 2014; Qiao et al., 2018; Tao et al., 2017; Wei et al., 2018; Yu et al., 2013). Organic aerosols (OAs) are composed of a complex mixture of diverse molecules (Xu et al., 2011). They play essential roles in global climate changes via the modification of radiative forcing and cause a serious negative impact on human health (Fuzzi et al., 2007). OAs contain various water-soluble organic compounds, which can act as cloud condensation nuclei (CCN) (Kanakidou et al., 2005).

BB is essentially a primary source of OAs, controlling the air quality levels and affecting the Earth's radiative forcing by scattering or absorbing incident solar radiation (Deshmukh et al., 2019a; Kanakidou et al., 2005; Kanaya et al. 2013; Streets et al., 2003; Sullivan et al., 2008). There are several kinds of BB, including industrial biofuel burning, open field burning (fires of the forest, peatlands, and agricultural wastes), and domestic BB burning for house heating and cooking, which emits $\mathrm{BB}$ products into the atmosphere (Akagi et al., 2011). The BB aerosols are subjected to longrange atmospheric transport once they are emitted into the atmosphere (Verma et al., 2015). Levoglucosan (1,6-anhydro$\beta$-D-glucopyranose) is a pyrolysis product of cellulose and hemicellulose, which is generally found to be major organic constituents in the BB-influenced aerosols (Simoneit et al., 1999, 2002). Levoglucosan has been reported as a specific tracer for BB aerosols (Engling et al., 2009).

Sugar compounds (SCs) are ubiquitous in the atmosphere from different geographical locations, including urban, forest, marine, and polar regions (Burshtein et al., 2011; Fu et al., 2010; Wan et al., 2017). SCs are emitted from algae, microbes, pollen, suspended soil particle, and associated biota into the atmosphere by various processes, and thus they are termed as primary biological aerosol particles (PBAPs) (Carvalho et al., 2003; Després et al., 2012; Elbert et al., 2007). The detailed study of bioaerosols has been emphasized in the past decades due to the global impact of microbes and fungi because they can travel long distances from the source regions by winds (Burshtein et al., 2011; Brown and Hovmoller, 2002; Yamaguchi et al., 2012). Fungi are essential microbes in the ecosystem, which discharge spores of 8 $186 \mathrm{Tg} \mathrm{yr}^{-1}$ into the atmospheric environment (Elbert et al., 2007; Heald and Spracklen, 2009). Sugar alcohols like arabitol and mannitol are enriched in fungal spores; thus, they are considered to be specific tracers (Bauer et al., 2008).

Davis et al. $(1988,1990)$ reported that mannitol was also found in about 70 different higher-plant families. Loescher et al. (1992) reported that mannitol is an important photosynthetic product converted by biosynthesis in plants. Keller and Matile (1989) also found arabitol and mannitol during the increased photosynthesis in growing vegetation. Pollen is the largest particle that could contribute up to $65 \%$ of the PBAPs, which are the significant sources for sucrose and fructose in the forest aerosols (Manninen et al., 2014; Pacini, 2000). Higher plants synthesize primary sugars (glucose, fructose, and sucrose) during photosynthesis, which are circulated by phloem to accumulate in root cells and to develop plant sections (Jaenicke, 2005; Jia et al., 2010; Pacini, 2000). Cowie et al. (1984) also reported various sugars in terrestrial plant fruits, flowers, and plant tissues. Bieleski (1995) reported that glucose, fructose, and sucrose are well-known components of microbes and invertebrates. The plant debris, as well as lichens, invertebrates, and soil dust, are also recognized as possible sources of primary sugars in the atmosphere (Medeiros et al., 2006; Rogge et al., 2007; Simoneit et al., 2004).

Previous studies analyzed aerosol samples for SCs and discussed several factors to control their local and global atmospheric levels. Recently, Xu et al. (2020) examined the seasonal molecular distributions of primary biological aerosols and BB aerosol samples collected from urban Beijing. They reported a high level of arabitol, mannitol, sucrose, glucose, and fructose in the vegetation-growing season. Kang et al. (2018) also reported higher concentrations of sugars in the urban aerosols from Beijing. They suggested a large contribution of coal combustion and agriculture residue burning under stable meteorological conditions in winter and spring. Verma et al. $(2015,2018)$ reported that the atmospheric circulations and long-range transport of organic aerosols and bioaerosols from East Asia significantly control the levels and compositions of SCs over the western North Pacific. The above studies discussed the several factors that affect the concentrations of SCs in the aerosol samples collected from urban and remote areas.

In this study, we conducted analyses of SCs in the aerosol samples collected from the northern vicinity of Beijing city in 2007. Here, we present comprehensive data sets of anhydrosugars, primary sugars, and sugar alcohols in the suburban aerosol samples and their diurnal variations to explain the source variance following the wind patterns in the dayand nighttime. The positive matrix factorization (PMF) has been applied to clarify the different sources of measured SCs in the aerosol. We present the influence of local meteorology of the sampling site and atmospheric transport from Beijing by southerly winds and from Mangshan National Forest Park by northerly winds on the molecular distributions of SCs. Using the mass concentration ratio of levoglucosan to mannosan, we explain the relative contribution of hard and softwood burning to the air quality of Mangshan. This study also discussed carbon contributions of SCs and BB measured in the Mangshan aerosol samples from different sources. 


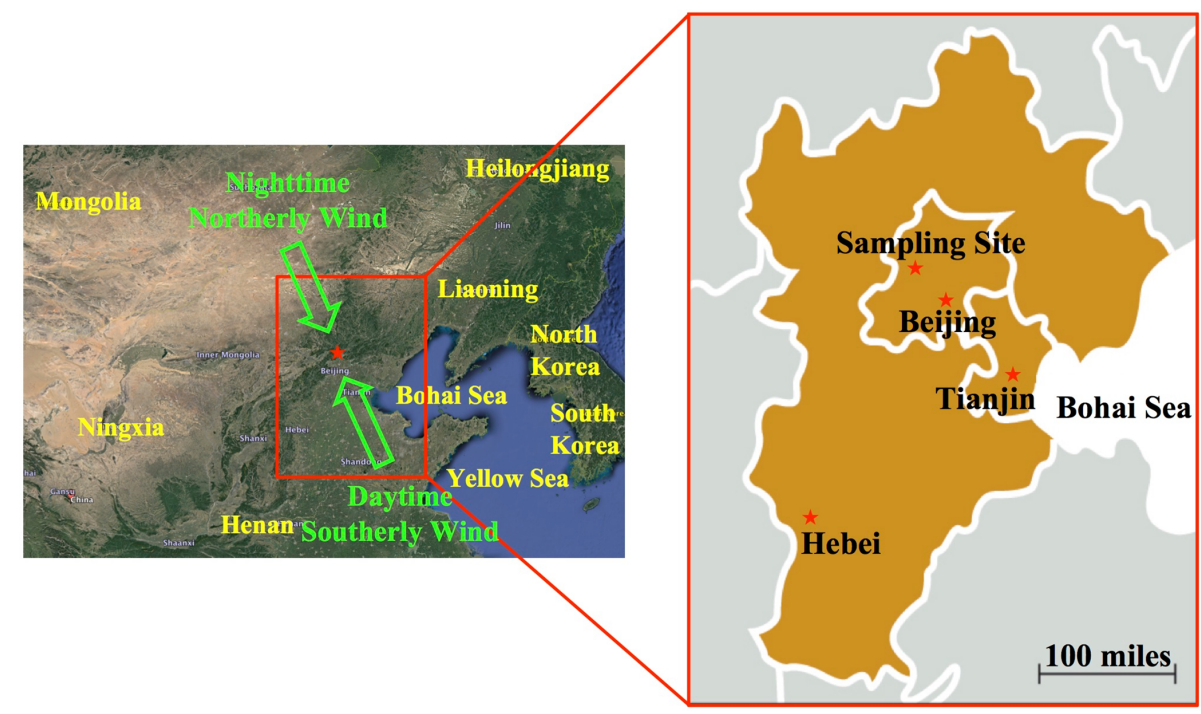

Figure 1. Geographical location of Mangshan, China. The map was downloaded from @ Google Maps 2019.

\section{Materials and methods}

\subsection{Site description and aerosol sample collection}

The sampling site (Mangshan: $40.28^{\circ} \mathrm{N}, 116.26^{\circ} \mathrm{E}$ ) is located $40 \mathrm{~km}$ north of Beijing. A detailed description of the sampling site is given in $\mathrm{He}$ et al. (2014, 2015). Briefly, Mangshan is surrounded by urban areas in the south and forest areas with the national park in the north (Fig. 1). The ambient temperature was higher in daytime $\left(23.9^{\circ} \mathrm{C}\right)$ than nighttime $\left(12.1^{\circ} \mathrm{C}\right)$, with an average of $17.8^{\circ} \mathrm{C}$ during the campaign. The relative humidity $(\mathrm{RH})$ varied significantly from $22.1 \%$ to $90.5 \%$, with an average of $51.7 \%$ during the study period. The rainfall was observed at midnight on 15 September, the morning of 17 to evening 18 September, and the night of 26 September, and light rain lasted from 4 October to the end of the campaign (Fig. 2a). Interestingly, the sampling site is characterized by a specific wind pattern; i.e., southwest wind $(69.9 \%)$ prevailed, followed by northeast wind $(23.4 \%)$ and southeast wind $(6.2 \%)$ during the daytime (Fig. 2a). The northeast wind $(99.5 \%)$ was dominated at night, which is consistent with the air mass back trajectories (He et al., 2014) (Fig. 2b). The daytime wind from the southwest direction passed over Beijing, delivering anthropogenic air mass to the Mangshan site.

Detailed descriptions of the total suspended particulate (TSP) samples collected at Mangshan are given in He et al. (2014, 2015). Briefly, The aerosol samples were collected near the entrance of Mangshan National Forest Park. The elevation of the sampling location is $187 \mathrm{~m}$ above sea level. A high-volume air sampler (Kimoto AS810A) at a flow rate of $1.13-1.17 \mathrm{~m}^{3} \mathrm{~min}^{-1}$ was used to collect the TSP without cutoff device. In the sampling, no denuder was applied to remove semi-volatile gases because the filter samples were used to analyze nonvolatile sugar compounds. However, the levoglucosan partitions are between the gas and particle phases, but the gaseous concentration should be low. The sampling time was rather short due to the day and night sampling. Therefore, the uncertainty due to the gas-particle partitioning might be insignificant. The samples were collected on precombusted $\left(450{ }^{\circ} \mathrm{C}\right.$ for $\left.6 \mathrm{~h}\right)$ quartz fiber filters (Pallflex 2500QAT-UP, $20 \mathrm{~cm} \times 25 \mathrm{~cm}$ ) from 15 September to 5 October 2007. After sample collection, the individual filters were placed in precombusted glass jars with Teflonlined screw caps and stored in a dark, cold room at $-20^{\circ} \mathrm{C}$ to prevent microbial activity and loss of semi-volatile organic compounds from the samples. In this study, a total of 58 filter samples were analyzed. We collected $3 \mathrm{~h}$ daytime (from 09:00 to $12: 00,12: 00$ to $15: 00$, and 15:00 to 18:00) $(n=26)$, $9 \mathrm{~h}$ daytime (from 09:00 to 18:00) $(n=12$ ), and $15 \mathrm{~h}$ nighttime (from 18:00 to 09:00) $(n=20)$ samples together with four field blanks. Table $\mathrm{S} 1$ shows the details of aerosol sample collection in the Mangshan site.

\subsection{Extraction and derivatization of samples}

A total of 58 aerosol samples were analyzed for anhydrosugars, primary sugars, and sugar alcohols (Table 1). The sample filters (approximately $21 \mathrm{~cm}^{2}$ ) were extracted with a dichloromethane and methanol mixture $(2: 1)$ under ultrasonication. Pasteur pipettes packed with precombusted quartz wool were used to filter the extracts to remove filter debris. After filtration, the extracts were concentrated in a rotary evaporator under vacuum and dried by nitrogen blowdown. The extracts were reacted with $60 \mu \mathrm{L}$ of N,O-bis(trimethylsilyl)trifluoroacetamide (BSTFA) with $1 \%$ trimethylsilyl (TMS) chloride in the presence of $10 \mu \mathrm{L}$ of pyridine at $70^{\circ} \mathrm{C}$ for $3 \mathrm{~h}$ to derivatize hydroxyl $(\mathrm{OH})$ and car- 
boxyl $(\mathrm{COOH})$ groups into corresponding TMS ethers and esters, respectively. After the reaction, $n$-hexane was used for dilution, and $\mathrm{C}_{13} n$-alkane was added as an internal standard before gas chromatography-mass spectrometry (GCMS) analysis.

\subsection{Gas chromatography-mass spectrometry determination of sugar compounds (SCs)}

Details of GC-MS operation and identification of SCs are described in Verma et al. $(2015,2018)$. Briefly, GC-MS analyses were performed on an Agilent model 6890 gas chromatograph (GC) combined with an Agilent model 5973 mass selective detector (MSD) to determine SCs. The mass spectrometer was operated in the electron ionization (EI) mode at $70 \mathrm{eV}$ with a scan range of $m / z$ 40-650. The GC separation was achieved on a DB-5MS fused silica capillary column ( $30 \mathrm{~m} \times 0.25 \mathrm{~mm}$ in diameter, $0.25 \mu \mathrm{m}$ film thickness) and a split/splitless injector. The GC oven temperature was programmed to maintain at $50^{\circ} \mathrm{C}$ for $2 \mathrm{~min}$ and then to increase from 50 to $120^{\circ} \mathrm{C}$ at a rate of $15^{\circ} \mathrm{C} \mathrm{min}^{-1}$ and then from 120 to $305^{\circ} \mathrm{C}$ at a rate of $5^{\circ} \mathrm{C} \mathrm{min}-1$. The final isotherm holds at $305^{\circ} \mathrm{C}$ for $15 \mathrm{~min}$. Helium was used as the carrier gas at a flow rate of $1.0 \mathrm{~mL} \mathrm{~min}^{-1}$. The sample was injected on a splitless mode at $280^{\circ} \mathrm{C}$ injector temperature. GC-MS data were acquired and processed with Agilent GC/MSD ChemStation software.

The individual compounds (TMS derivatives) were identified by comparing the relative response factors determined by the injection of authentic standards and those reported in the literature and library texts (Claeys et al., 2004). Fragment ions of sugar compounds at 217 and 204 were used for quantifications. In total 10 sugar compounds, including three anhydrosugars (levoglucosan, galactosan, mannosan), four primary sugars (glucose, fructose, sucrose, trehalose, and xylose), and three sugar alcohols (arabitol, mannitol, and inositol), were detected in the Mangshan aerosols. Field blanks were treated as a real sample and analyzed by the procedure used for the real samples. Recoveries for SCs were better than $85 \%$ as obtained for the standards spiked onto a precombusted quartz filter followed by extraction and derivatization. Based on the duplicate analysis, the analytical errors in the concentrations of the detected compounds were obtained to be within $10 \%$. The detection limits of SCs correspond to ambient concentrations of $150-620 \mathrm{pg} \mathrm{L}^{-1}$, which corresponds to ambient concentrations of $15-70 \mathrm{pg} \mathrm{m}^{-3}$ under a typical sampling volume of $900 \mathrm{~m}^{3}$.

\subsection{Chemical analyses of organic carbon (OC), water-soluble organic carbon (WSOC), and inorganic ions}

The data set and methods for the determination of organic carbon (OC), water-soluble organic carbon (WSOC), and inorganic ion $\left(\mathrm{Ca}^{2+}\right)$ were reported in $\mathrm{He}$ et al. (2015).
Briefly, the concentrations of OC were measured using a semi-continuous OC / EC analyzer (Sunset Laboratory Inc., Portland, OR, USA). A punch of the filter $(\Phi 14 \mathrm{~mm})$ was placed in a quartz boat inside the thermal desorption chamber of the analyzer, and then stepwise heating (IMPROVE) was applied. The oven temperature was programmed as follows: under He, every $2 \mathrm{~min}$, the oven temperature was increased starting from $250^{\circ} \mathrm{C}$ for $2 \mathrm{~min}$, at $450^{\circ} \mathrm{C}$ for $2 \mathrm{~min}$, and at $550^{\circ} \mathrm{C}$ for $2 \mathrm{~min}$. After that, $550^{\circ} \mathrm{C}$ was maintained for 2 min under $\mathrm{He}$ mixed with $10 \% \mathrm{O}_{2}$, then at $700{ }^{\circ} \mathrm{C}$ for $2 \mathrm{~min}$, and at $870^{\circ} \mathrm{C}$ for $3.5 \mathrm{~min}$. An NDIR detector was used to determine $\mathrm{CO}_{2}$ generated in the above process (Wang et al., 2005). The carbon content of the sample that evolves to $\mathrm{CO}_{2}$ between 250 and $700^{\circ} \mathrm{C}$ was defined as $\mathrm{OC}$.

Aliquots of the filter samples $\left(3.14 \mathrm{~cm}^{2}\right)$ were extracted with Milli-Q water for the water-soluble inorganic ion and WSOC measurements. After extraction, one part was used for the analyses of inorganic ions $\left(\mathrm{SO}_{4}^{2-}, \mathrm{NO}_{3}^{-}, \mathrm{Cl}^{-}, \mathrm{NH}_{4}^{+}\right.$, $\mathrm{Na}^{+}, \mathrm{Ca}^{2+}, \mathrm{K}^{+}$, and $\mathrm{Mg}^{2+}$ ) using an ion chromatography (IC) system (761 Compact IC, Metrohm, Switzerland). Cations on a Shodex YK-421 column with $4 \mathrm{mM} \mathrm{H}_{3} \mathrm{PO}_{4}$ as eluent and anions were separated on a Shodex SI-90 4E column with $1.8 \mathrm{mMNa}_{2} \mathrm{CO}_{3}$ and $1.7 \mathrm{mMNaHCO}_{3}$ as eluent. The injection loop volume was $200 \mu \mathrm{L}$. Both cations and anions were quantified against a standard calibration curve. Another part of the filtered water extract was acidified with $1.2 \mathrm{M} \mathrm{HCl}$ and purged with pure air to remove dissolved inorganic carbon and volatile organics. Then WSOC was measured with a carbon analyzer (Shimadzu, TOC-5000). Procedural blanks were carried out in parallel with real samples to account for any contamination (He et al., 2015).

\subsection{Positive matrix factorization (PMF) analysis}

Positive matrix factorization (PMF) is a powerful statistical tool for resolving the potential sources contributing to atmospheric particles (Paatero and Tapper, 1994). The measured ambient concentrations and method detection limits (MDLs) of SCs were used to calculate the uncertainties. The measured concentrations of SCs below or equal to the MDLs were replaced by half of the MDL, and associated uncertainties were set at $5 / 6$ of the MDL [(5/6) $\times$ MDL] values of each sample. The geometric mean concentrations were used for missing concentrations, and the uncertainty of the concentrations greater than the MDL was calculated based on the following equation:

Uncertainty $=$

$\sqrt{(\text { error fraction } \times \text { concentration })^{2}+(0.5 \times \mathrm{MDL})^{2}}$.

The error fraction is a user-provided estimation of the analytical uncertainty of the measured concentration or flux. For example, Han et al. (2017) used an error fraction of 0.2-0.3 for organics and 0.2 for all the species. In this work, the error fraction was set to be 0.3 for all species. Paatero et al. (2002) 
Table 1. Minimum, maximum, and average concentrations with standard deviations for sugar compounds in aerosol samples (TSP) from Mangshan, China.

\begin{tabular}{|c|c|c|c|c|c|c|c|c|c|c|c|c|}
\hline \multirow[t]{2}{*}{ Sugar compounds } & \multicolumn{4}{|c|}{ Overall } & \multicolumn{4}{|c|}{ Daytime $(n=38)$} & \multicolumn{4}{|c|}{ Nighttime $(n=20)$} \\
\hline & Min & Max & Avg. & SD & Min & $\operatorname{Max}$ & Avg. & SD & Min & Max & Avg. & SD \\
\hline \multicolumn{13}{|l|}{ Anhydrosugars } \\
\hline Galactosan & 0.14 & 48.0 & 10.1 & 11.9 & 0.14 & 45.3 & 8.53 & 10.5 & 0.69 & 48.0 & 13.0 & 14.0 \\
\hline Mannosan & 0.13 & 26.1 & 6.05 & 6.33 & 0.13 & 24.3 & 5.37 & 6.01 & 0.53 & 26.1 & 7.35 & 6.87 \\
\hline Levoglucosan & 1.17 & 482 & 100 & 119 & 1.17 & 418 & 83.2 & 106 & 5.66 & 482 & 132 & 138 \\
\hline \multicolumn{13}{|l|}{ Sugar alcohols } \\
\hline Arabitol & 3.89 & 72.2 & 29.1 & 21.5 & 3.99 & 72.2 & 32.5 & 22.0 & 3.89 & 71.3 & 22.5 & 19.4 \\
\hline Mannitol & 4.19 & 182 & 44.1 & 34.5 & 4.19 & 182 & 51.7 & 37.5 & 4.40 & 87.7 & 29.6 & 22.3 \\
\hline Inositol & 0.23 & 6.8 & 2.62 & 1.81 & 0.27 & 6.80 & 3.14 & 1.90 & 0.23 & 4.65 & 1.62 & 1.09 \\
\hline \multicolumn{13}{|l|}{ Primary sugars } \\
\hline Fructose & 1.72 & 177 & 20.1 & 24.6 & 1.72 & 177 & 23.9 & 29.3 & 2.64 & 30.9 & 12.8 & 7.67 \\
\hline Glucose & 1.86 & 297 & 40.0 & 43.4 & 1.86 & 297 & 44.2 & 50.8 & 4.52 & 108 & 32.0 & 22.8 \\
\hline Sucrose & 0.02 & 474 & 58.5 & 96.5 & 0.02 & 474 & 82.9 & 112 & 0.04 & 60.1 & 12.3 & 15.1 \\
\hline Trehalose & 0.06 & 39.5 & 14.3 & 10.5 & 0.06 & 34.9 & 15.3 & 10.6 & 0.87 & 39.5 & 12.3 & 10.2 \\
\hline Anhydrosugars & 6.01 & 556 & 116 & 137 & 6.01 & 476 & 97.1 & 122 & 6.88 & 556 & 152 & 159 \\
\hline Primary sugars & 9.41 & 565 & 133 & 125 & 9.41 & 565 & 166 & 141 & 10.5 & 172 & 69.4 & 43.0 \\
\hline Sugar alcohols & 8.53 & 259 & 75.8 & 54.7 & 9.09 & 259 & 87.4 & 57.5 & 8.53 & 164 & 53.7 & 41.9 \\
\hline Total sugars & 30.8 & 875 & 325 & 232 & 34.1 & 875 & 351 & 240 & 30.8 & 759 & 276 & 212 \\
\hline Anhydrosugars (\%) & & & 31.9 & & & & 24.6 & & & & 45.7 & \\
\hline Primary sugars (\%) & & & 41.8 & & & & 47.3 & & & & 31.3 & \\
\hline Sugar alcohols $(\%)$ & & & 26.4 & & & & 28.1 & & & & 23.0 & \\
\hline
\end{tabular}

and Zhou et al. (2004) reported detailed discussions of the determination and application of PMF analysis.

\section{Results and discussion}

\subsection{Ambient concentrations and diurnal variations of SCs}

We detected a total of $10 \mathrm{SCs}$, including three anhydrosugars, four primary sugars, and three sugar alcohols in the Mangshan aerosol samples. Figure $3 a-c$ showed the temporal variations and Table 1 showed minimum, maximum, and average concentrations of anhydrosugars, primary sugars, and sugar alcohols with a standard deviation. The overall concentrations of SCs varied from $30.8-875 \mathrm{ng} \mathrm{m}^{-3}$ (avg. $\left.325 \mathrm{ng} \mathrm{m}^{-3}\right)$, which was higher in the daytime $\left(315 \mathrm{ng} \mathrm{m}^{-3}\right)$ and lower at nighttime $\left(276 \mathrm{ng} \mathrm{m}^{-3}\right)$; however, we did not observe statistically significant differences (Student $t$ test, $95 \%$ confidence interval, $p>0.05$ ) in their atmospheric abundances. Interestingly, higher average concentrations of SCs were reported for the aerosol samples collected at Mt. Tai (daytime $640 \mathrm{ng} \mathrm{m}^{-3}$ and nighttime $799 \mathrm{ng} \mathrm{m}^{-3}$ ) in the North China Plain (Fu et al., 2008) than the Mangshan aerosol. The diurnal concentrations of SCs may be significantly in- fluenced by vegetation and BB activities in the Mangshan site. SCs are significantly contributed by plant fractions and fungus from the forest area (Zhu et al., 2016). The meteorological parameters also affect the concentrations of SCs in the forest site (Miyazaki et al., 2012).

In addition, anthropogenic aerosols emitted from urban areas are probably transported to the northern receptor site in daytime by a southerly wind (He et al., 2014, 2015). Therefore, the high levels of SCs in daytime may be related to the transport of organic aerosols and bioaerosols from urban regions. At nighttime, the wind direction is shifted to northerly, delivering comparatively clean air masses from the Mangshan National Forest area to the sampling site. Air mass from the forest may significantly contribute to nighttime SCs in the Mangshan site. The influence of local sources and longrange-transported aerosols on the SCs will be discussed in Sect. 3.1.1 to 3.1.3.

\subsubsection{Ambient concentrations and diurnal variations of anhydrosugars}

The average concentrations of anhydrosugars were found to be $116 \mathrm{ng} \mathrm{m}^{-3}$, contributing $31.9 \%$ of overall SCs in the Mangshan aerosols (Table 1). Figure $4 \mathrm{a}-\mathrm{c}$ show the temporal variations of anhydrosugars. They are more abun- 

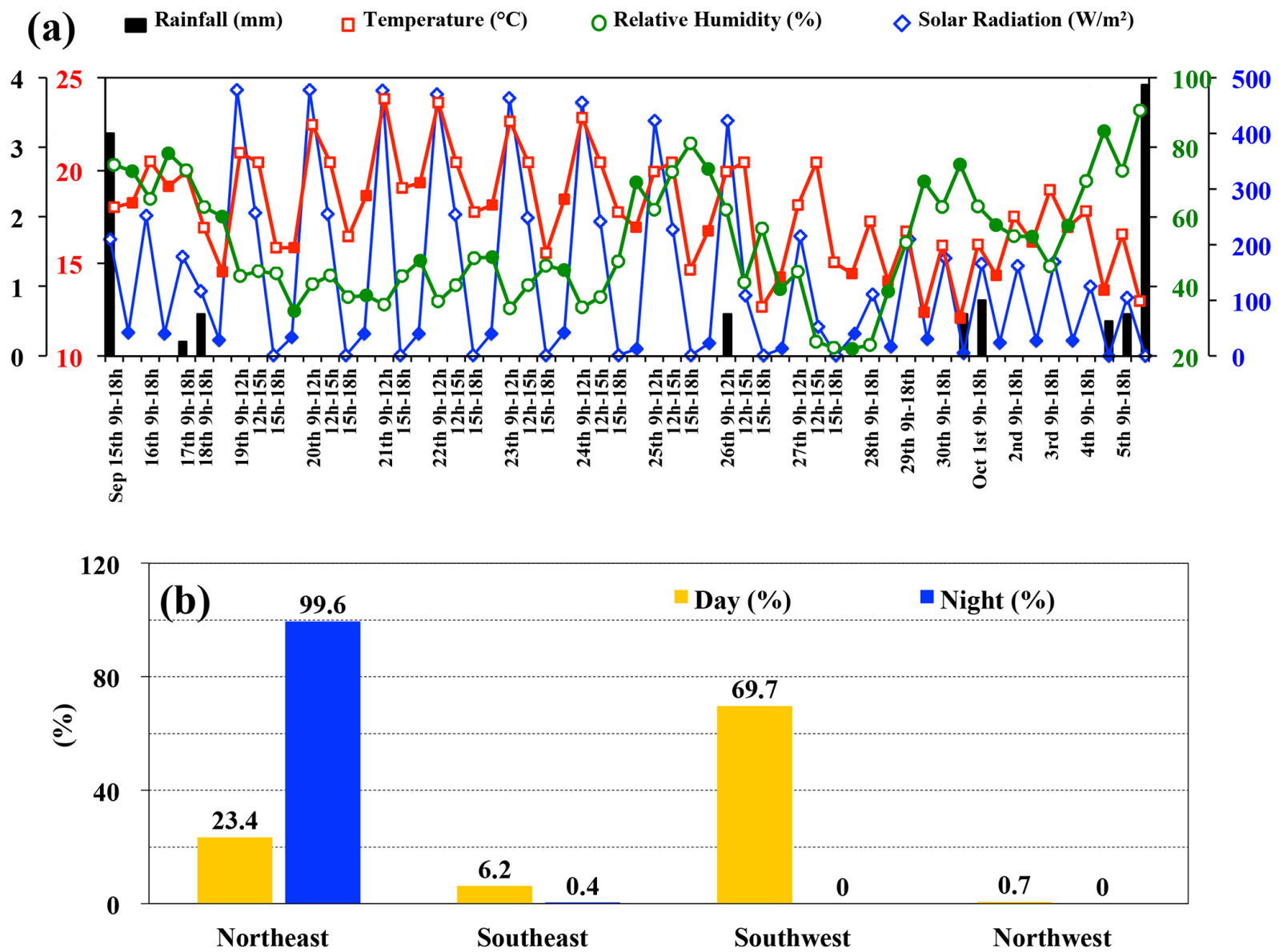

Wind direction

Figure 2. (a) The meteorological parameters at Mangshan during sampling periods. (b) Fractions of local wind directions at the Mangshan site, north of Beijing, China.

dant at nighttime (avg. $152 \mathrm{ng} \mathrm{m}^{-3}$ ) than daytime (avg. $\left.97.1 \mathrm{ng} \mathrm{m}^{-3}\right)$. Levoglucosan $\left(100 \mathrm{ng} \mathrm{m}^{-3}\right)$ is the most abundant anhydrosugar followed by galactosan $\left(10.1 \mathrm{ng} \mathrm{m}^{-3}\right)$ and mannosan $\left(6.05 \mathrm{ng} \mathrm{m}^{-3}\right.$ ) detected in Mangshan aerosols. Kang et al. (2018) reported high levels of levoglucosan (avg. $110 \mathrm{ng} \mathrm{m}^{-3}$ ) in autumn aerosols from Beijing, China. It is well known that biofuel burning is the common energy source for cooking and house heating in China in winter and autumn (Verma et al., 2015); thus the domestic BB activities in the surroundings of the Mangshan site significantly contribute to the levoglucosan. BB tracers showed significant positive correlations with each other (levoglucosan and galactosan, $r=0.98$; levoglucosan and mannosan, $r=0.97$; galactosan and mannosan, $r=0.98$ ), suggesting their similar sources in the Mangshan aerosols (Table 2).

The levoglucosan concentrations showed significant diurnal variations, which were higher at nighttime (avg. $132 \mathrm{ng} \mathrm{m}^{-3}$ ) than daytime (avg. 83.2 $\mathrm{ng} \mathrm{m}^{-3}$ ) (Table 1). A similar diurnal pattern was also found for the concentrations of galactosan and mannosan. The increased concentrations of
BB tracers were observed during the periods of lower ambient temperature (Figs. 2a, 4a-c). The higher ambient temperature was recorded in daytime between 09:00 to 15:00 during the campaign, associated with decreased BB activities. In this sequence, the nighttime samples were collected from 18:00 to 09:00, including peak hours of BB for domestic purpose. Therefore, it is reasonable to detect higher abundances of BB tracers in the nighttime than daytime. Hence, it is evident that BB activities were increased at night because of cooking and house heating at a cool night in autumn. In addition, recent studies reported the widespread BB aerosols in the North China Plain, including megacities such as Beijing, Nanjing, Hebei, and Tianjin (Lelieveld et al., 2015; Kawamura et al., 2013; Li et al., 2010; Sun et al., 2016). Therefore, the atmospheric transport of $\mathrm{BB}$ aerosols from the urban area to the Mangshan site by southerly winds cannot be excluded. The diurnal variations of levoglucosan may be significantly influenced by the local BB activities and transported BB aerosols from urban areas, where BB products are generated by brown coal combustion (Yan et al., 2018). 
Table 2. Statistical summary of correlations among the chemical species and meteorological variables in aerosol samples collected at a forest site in northern Japan.

\begin{tabular}{|c|c|c|c|}
\hline Linear regression & $\begin{array}{r}\text { Correlation } \\
\text { coefficient }\end{array}$ & $p$ value & $\begin{array}{l}\text { Significance of } \\
\text { correlation at } \\
p \text { value }<0.05\end{array}$ \\
\hline \multicolumn{4}{|l|}{ Overall $(n=58)$} \\
\hline Levoglucosan vs. galactosan & 0.98 & $<0.05$ & Significant \\
\hline Levoglucosan vs. mannosan & 0.97 & $<0.05$ & Significant \\
\hline Mannosan vs. galactosan & 0.98 & $<0.05$ & Significant \\
\hline Sucrose vs. temperature & 0.52 & $<0.05$ & Significant \\
\hline Sucrose vs. solar radiation & 0.55 & $<0.05$ & Significant \\
\hline Arabitol vs. mannitol & 0.81 & $<0.05$ & Significant \\
\hline Arabitol vs. RH & 0.69 & $<0.05$ & Significant \\
\hline Mannitol vs. RH & 0.57 & $<0.05$ & Significant \\
\hline Glucose vs. fructose & 0.94 & $<0.05$ & Significant \\
\hline Trehalose vs. arabitol & 0.58 & $<0.05$ & Significant \\
\hline Trehalose vs. mannitol & 0.58 & $<0.05$ & Significant \\
\hline Trehalose vs. $\mathrm{Ca}^{2+}$ & 0.70 & $<0.05$ & Significant \\
\hline \multicolumn{4}{|l|}{ Daytime $(n=38)$} \\
\hline Sucrose vs. $\mathrm{Ca}^{2+}$ & 0.32 & $>0.05$ & Not significant \\
\hline Glucose vs. $\mathrm{Ca}^{2+}$ & 0.02 & $>0.05$ & Not significant \\
\hline Trehalose vs. arabitol & 0.49 & $<0.05$ & Significant \\
\hline Trehalose vs. mannitol & 0.51 & $<0.05$ & Significant \\
\hline Trehalose vs. $\mathrm{Ca}^{2+}$ & 0.81 & $<0.05$ & Significant \\
\hline Fructose vs. mannitol & 0.79 & $<0.05$ & Significant \\
\hline Levoglucosan vs. OC & 0.45 & $<0.05$ & Significant \\
\hline Levoglucosan vs. WSOC & 0.40 & $<0.05$ & Significant \\
\hline \multicolumn{4}{|l|}{ Nighttime $(n=20)$} \\
\hline Sucrose vs. $\mathrm{Ca}^{2+}$ & 0.37 & $>0.05$ & Not significant \\
\hline Glucose vs. $\mathrm{Ca}^{2+}$ & 0.27 & $>0.05$ & Not significant \\
\hline Trehalose vs. arabitol & 0.76 & $<0.05$ & Significant \\
\hline Trehalose vs. mannitol & 0.85 & $<0.05$ & Significant \\
\hline Trehalose vs. $\mathrm{Ca}^{2+}$ & 0.61 & $<0.05$ & Significant \\
\hline Fructose vs. mannitol & 0.86 & $<0.05$ & Significant \\
\hline Levoglucosan vs. OC & 0.81 & $<0.05$ & Significant \\
\hline Levoglucosan vs. WSOC & 0.70 & $<0.05$ & Significant \\
\hline
\end{tabular}

The data of $\mathrm{Ca}^{2+}$, OC, and WSOC are adapted from He et al. (2015).

\subsubsection{Ambient concentrations and diurnal variations of primary sugars}

The fragment of vascular plants contains primary sugars, including glucose, fructose, sucrose, and trehalose (Medeiros et al., 2006). Primary sugars were found to be the most abundant sugars (avg. $133 \mathrm{ng} \mathrm{m}^{-3}$ ), contributing to $41.8 \%$ of the total SCs in Mangshan aerosols (Table 1). They showed apparent diurnal variations with daytime high (avg. $166 \mathrm{ng} \mathrm{m}^{-3}$ ) and nighttime low values (avg. $69.4 \mathrm{ng} \mathrm{m}^{-3}$ ) (Figs. 3a-c, 5a-d). Graham et al. (2003) also reported similar diurnal variations of primary sugars for the Amazon forest aerosols. Sucrose was found to be the dominant primary sugar (avg. $58.5 \mathrm{ng} \mathrm{m}^{-3}$ ), accounting for $44 \%$ of measured primary sugars in Mangshan aerosols (Table 1). Pollen was reported as a primary source for sucrose in aerosols collected from a Texas rural site (Jia et al., 2010). Fu et al. (2012) found high sucrose concentrations up to $1390 \mathrm{ng} \mathrm{m}^{-3}$ in the aerosols from Jeju Island, South Korea. Therefore, the plant materials, including pollen spores from the local vegetation of Mangshan National Forest Park, are likely the primary source of sucrose in the aerosols. Miyazaki et al. (2012) also reported higher sucrose concentrations in the aerosol samples collected from the Hokkaido deciduous forest.

We found a significant diurnal variation of sucrose with higher daytime $\left(82.9 \mathrm{ng} \mathrm{m}^{-3}\right)$ than nighttime $\left(12.3 \mathrm{ng} \mathrm{m}^{-3}\right)$ concentration. Meteorological parameters such as tempera- 


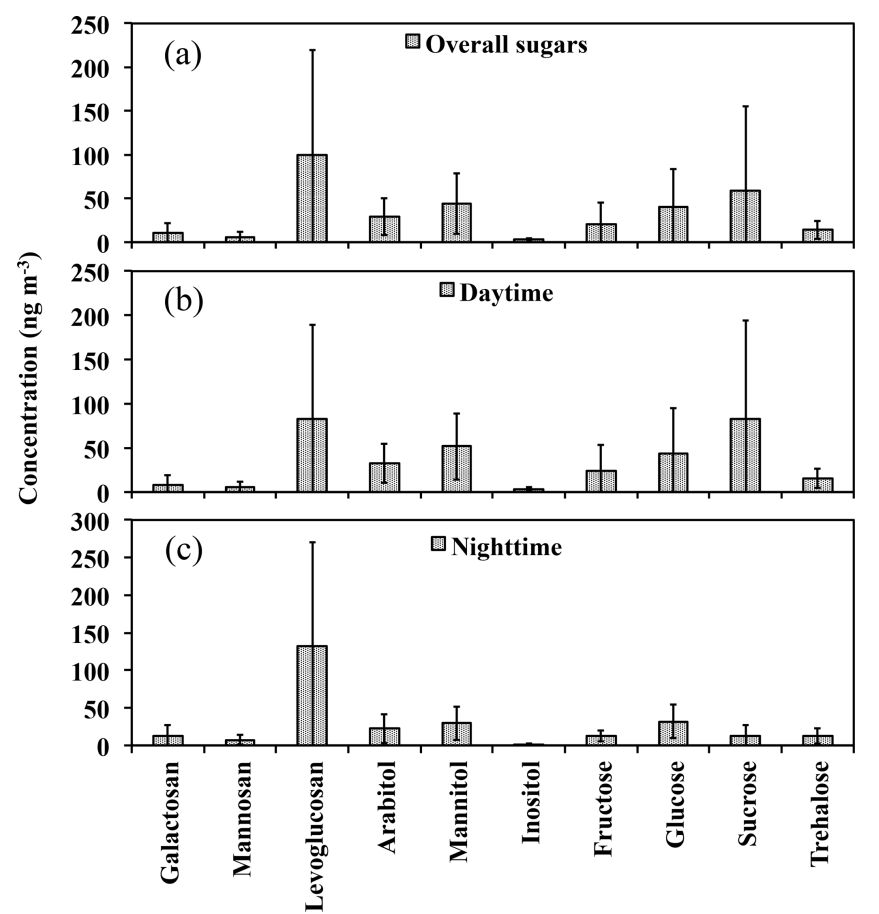

Figure 3. Concentrations $\left(\mathrm{ng} \mathrm{m}^{-3}\right.$ ) of sugar compound (a) overall, (b) in the daytime, and (c) at nighttime in aerosol samples from Mangshan during September-October 2007 (the error bars denote the standard deviation).

ture, rainfall, wind speed, and solar radiation significantly influence pollen activities and, subsequently, sucrose concentrations (Verma et al., 2018). Interestingly, an elevated peak of sucrose was observed from 12:00 to 15:00 with higher ambient temperature. In contrast, lower sucrose concentrations were observed from 15:00 to 09:00 with lower ambient temperature (Fig. 5a). Daytime increased concentrations of sucrose might be related to the higher daytime ambient temperature, low RH, and high solar radiation (Miyazaki et al., 2012). Taylor et al. (2002) reported the influence of the meteorological conditions, i.e., strong daytime winds and convective activity, which can result in catapulting of pollen, result in the opening of pollen-laden flower anthers, and cause enhanced entrainment and dispersal of the particles into the air. Pacini (2000) reported that higher levels of sucrose in daytime coincide with higher counts of pollen, fern spores, and insects. The positive linear correlations of sucrose with ambient temperature $(r=0.52)$ and solar radiation $(r=0.55)$ further supported the influence of meteorological parameters in the sucrose concentration (Table 2).

Five rain events were recorded during the campaign, i.e., 15, 17, 18, and 26 September and 1 and 5 October (Fig. 2a). Pollen is significantly settled down by wet scavenging during rain events because its size is large. A low concentration of sucrose was found from the beginning of sampling to the morning of 20 September and from the after- noon of 26 September to the end of the sampling campaign (Fig. 5a). In addition, the increased concentrations of sucrose were found in the aerosol samples collected from 20 to 22 September, and moderate concentrations were observed after 23 September to the evening of 25 September during non-precipitation events. Consequently, pollen was significantly scavenged during wet precipitation and washout effect from the atmosphere, resulting in lower sucrose concentrations at the earlier periods than later periods. In addition, Rogge et al. (2007) reported that surface soil dust and unpaved road dust also contribute sucrose in the atmospheric aerosols. However, insignificant correlations between sucrose and $\mathrm{Ca}^{2+}$ (daytime, $r=0.32$; nighttime, $r=0.37$ ) do not support soil dust contributions to sucrose in the Mangshan aerosols (Table 2).

Glucose was the second dominant primary sugar in the Mangshan aerosols. The average concentrations of glucose and fructose were observed to be 40.0 and $20.1 \mathrm{ng} \mathrm{m}^{-3}$, respectively (Table 1, Fig. 5b). The sampling site is characterized by the dense vegetation in the Mangshan National Forest Park. Therefore, the nectars and fruits of vegetation (Baker et al., 1998), plant debris (Medeiros et al., 2006), and pollen (Fu et al., 2012) in the forest significantly contribute to glucose and fructose. The glucose levels are equivalent to that $\left(50.1 \mathrm{ng} \mathrm{m}^{-3}\right)$ reported from the Howland Experimental Forest site in the USA (Medeiros et al., 2006). Glucose and fructose showed significant diurnal variations, whose concentrations were higher in daytime (44.2 and $23.9 \mathrm{ng} \mathrm{m}^{-3}$, respectively) than nighttime ( 32.0 and $12.8 \mathrm{ng} \mathrm{m}^{-3}$, respectively) in Mangshan aerosols (Table 1, Figs. 3b, c, 5b, c). This diurnal variation could be involved with emissions of pollen, fern spores, and other giant particles by strong winds (Graham et al., 2003; Pacini, 2000). Similar trends of glucose and fructose were reported in the Amazon forest, coinciding with plant fragments and insects (Graham et al., 2003). The autumn decay of vascular plant leaves in the Mangshan forest may have contributed to the levels of glucose and fructose.

Although, the daytime southerly winds deliver anthropogenic air masses from megacities to the sampling site. The daytime winds from the northeast direction $(23.4 \%)$ also carry air masses from the forest region, transporting primary sugars to the Mangshan site. However, in $99.5 \%$ of the nighttime hours, the wind is shifted to northeasterly, i.e., in forest region (He et al., 2015), but the emissions of primary sugars at night in the form of plant fragments are lower than in daytime, because the daytime ambient temperature and solar radiation significantly induce the emissions of sugar compounds in the forest site (Miyazaki et al., 2012). Therefore, low glucose and fructose levels were found at nighttime compared to daytime aerosols at the Mangshan site (Table 1, Fig. 3). Previous studies have reported lichens (Dahlman et al., 2003) and soil dust (Nolte et al., 2001; Rogge et al., 2007) as significant sources of both primary sugars. The concentration of glucose was insignificantly correlated with soil tracer $\left(\mathrm{Ca}^{2+}\right)$ in daytime $(r=0.02)$ and 


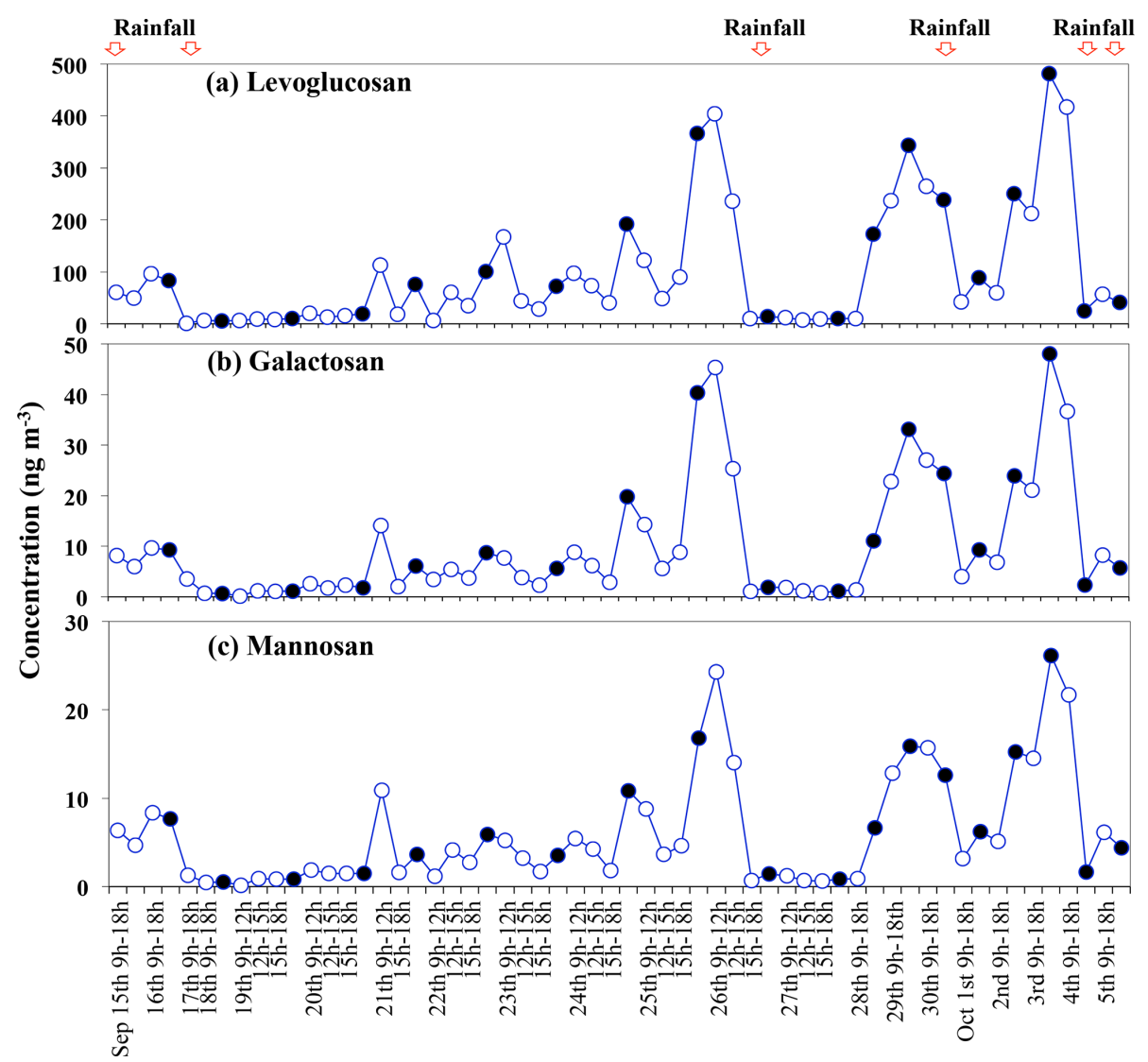

Figure 4. Temporal variations in the concentrations $\left(\mathrm{ng} \mathrm{m}^{-3}\right)$ of anhydrosugars in the Mangshan aerosol samples collected for SeptemberOctober 2007 (solid circle represents nighttime samples collected from 18:00 to 09:00; hollow circle represents daytime samples).

nighttime ( $r=0.27)$, denying their soil dust contributions in Mangshan aerosol samples.

Trehalose in the environment is significantly controlled by the activities of bacteria, fungi, yeast, algae, invertebrates, and plant species, as well as suspended soil particles (Medeiros et al., 2006, Rogge et al., 2007). The average concentration of trehalose was found to be $14.3 \mathrm{ng} \mathrm{m}^{-3}$ (Table 1, Fig. 5d). Yttri et al. (2007) reported higher trehalose concentrations in the aerosol samples collected from urban $\left(29 \mathrm{ng} \mathrm{m}^{-3}\right)$ and suburban $\left(27 \mathrm{ng} \mathrm{m}^{-3}\right)$ than rural $\left(3.8 \mathrm{ng} \mathrm{m}^{-3}\right)$ areas in Norway. The above results emphasize that fungi and microbes associated with anthropogenic and bioaerosols, emitted in the urban and suburban areas, might be responsible for the trehalose concentration in aerosol samples (Verma et al., 2018). Trehalose showed insignificant diurnal variation, whose day and night concentrations were observed to be 15.3 and $12.3 \mathrm{ng} \mathrm{m}^{-3}$, respectively, indicating its different emission sources in day and night for Mangshan aerosols (Figs. 3b, c, 5d).

The southerly winds might transport fungi and microbes associated with bioaerosols and eject spores under favorable meteorological conditions (high RH and low temperature) (Jones and Mitchell et al., 1996). Several microbes and fungi discharge spores at nighttime due to high-RH conditions (Ibrahim et al., 2011; Kim and Xiao, 2005; Malik and Singh, 2004; Sharma and Razak, 2003). Interestingly, trehalose is more significantly correlated with arabitol and mannitol ( $r=0.76$ and 0.85 , respectively) at nighttime than daytime ( $r=0.49$ and 0.51 , respectively) (Table 2), suggesting that fungal and microbial spores contributed to high levels of trehalose at nighttime. Hackl et al. (2000) found trehalose to be the dominant sugar in spring aerosols and proposed it as a tracer for soil dust particles. Trehalose concentration was more significantly correlated with $\mathrm{Ca}^{2+}(r=0.82)$ in daytime than nighttime $(r=0.61)$, indicating soil dust contribution (Table 2). Therefore, we hypothesized that winds transported soil particles from the urban area in daytime due to the active building constructions (He et al., 2015), contributing to the high levels of trehalose in daytime.

\subsubsection{Ambient concentrations and diurnal variations of sugar alcohols}

The average concentrations of sugar alcohols were found to be $75.8 \mathrm{ng} \mathrm{m}^{-3}$, contributing $26.4 \%$ of total SCs measured in Mangshan aerosols (Table 1). Sugar alcohols showed clear diurnal variations in daytime high (avg. $87.4 \mathrm{ng} \mathrm{m}^{-3}$ ) and 


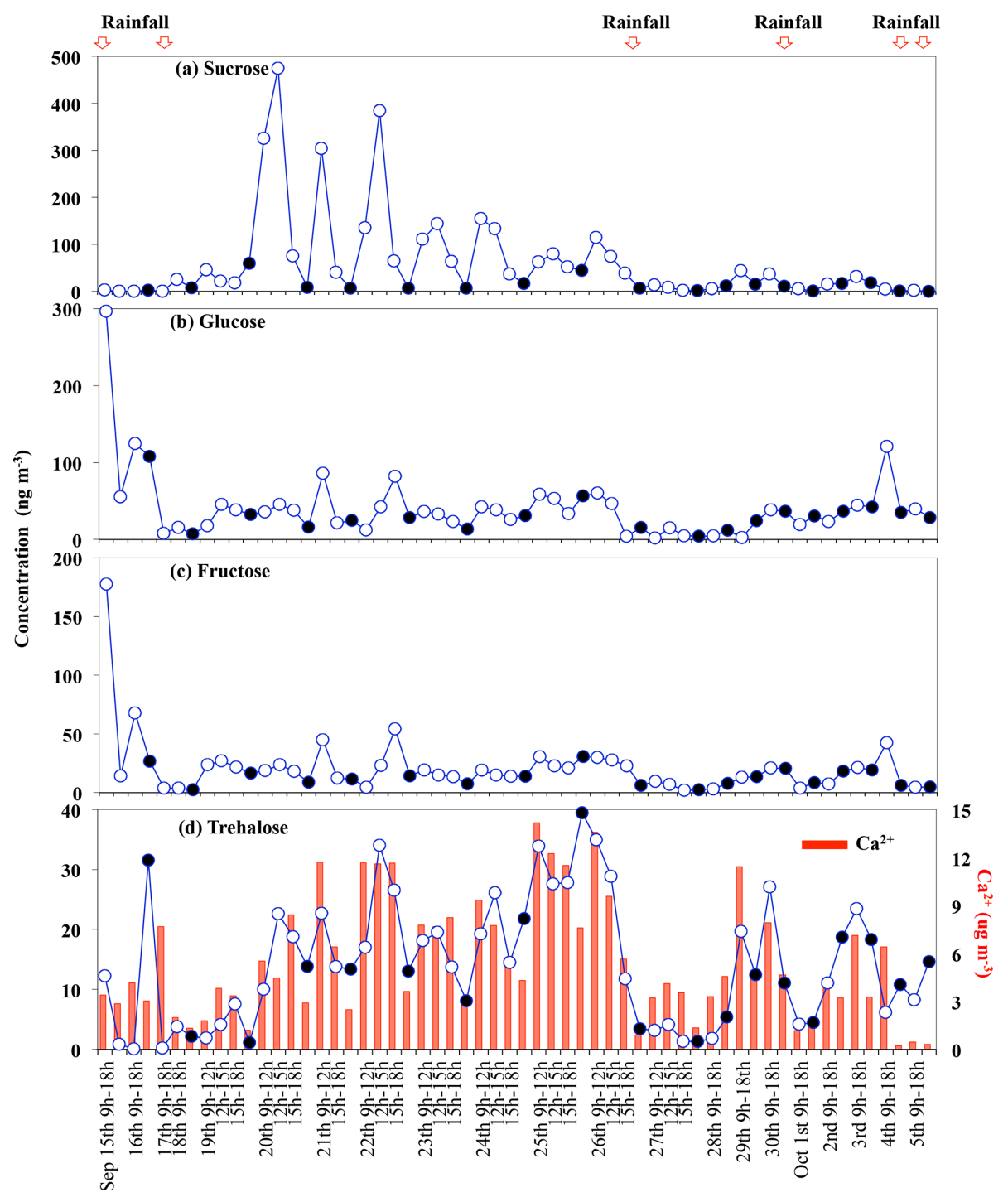

Figure 5. Temporal variations in the concentrations $\left(\mathrm{ng} \mathrm{m}^{-3}\right)$ of primary sugars in the Mangshan aerosol samples collected for SeptemberOctober 2007 (solid circle represents nighttime samples collected from 18:00 to 09:00; hollow circle represents daytime samples). The $y$ axis shows temporal variations in the concentrations $\left(\mu \mathrm{g} \mathrm{m}^{-3}\right)$ of $\mathrm{Ca}^{2+}$.

nighttime low (avg. $53.7 \mathrm{ng} \mathrm{m}^{-3}$ ) (Table 1). Mannitol was found to be the dominant sugar alcohol (avg. $44.1 \mathrm{ng} \mathrm{m}^{-3}$ ), followed by arabitol (avg. 29.1 $\mathrm{ng} \mathrm{m}^{-3}$ ) and inositol (avg. $2.62 \mathrm{ng} \mathrm{m}^{-3}$ ) (Table 1; Fig. 6a-c). Mannitol and arabitol are common polyols detected in green algae, lichens, and fungal spores (Bieleski, 1995, Dahlman et al., 2003; Filippo et al., 2013; Lewis and Smith, 1967; Yttri et al., 2007). Previous studies have reported that arabitol and mannitol are key components of fungal spores, and thus they are considered to be fungal tracers (Bieleski,1995; Lewis and Smith, 1967). Several fungal and microbial species released spores during biological activities into the atmosphere (Dahlman et al., 2003; Bauer et al., 2008; Filippo et al., 2013). Therefore, the autumn time fungal and microbial species significantly contribute to arabitol and mannitol in the Mangshan aerosol samples.

However, mannitol and arabitol showed a strong positive linear correlation $(r=0.81)$, which suggested common origins as reported in earlier studies (Fu et al., 2012) (Table 2). In contrast, the higher concentration of mannitol than arabitol suggested it had sources in addition to fungal spores in the Mangshan forest site. In this sequence, several previous studies have confirmed the significance of mannitol in plant photosynthesis (Loescher et al., 1992; Keller and Matile, 1989; Rumpho et al., 1983). Pashynska et al. (2002) reported that detritus of mature leaves can emit mannitol into the atmosphere by wind action. Heald and Spracklen (2009) also found a correlation between the atmospheric water vapor with mannitol concentrations and leaf area index. They sug- 


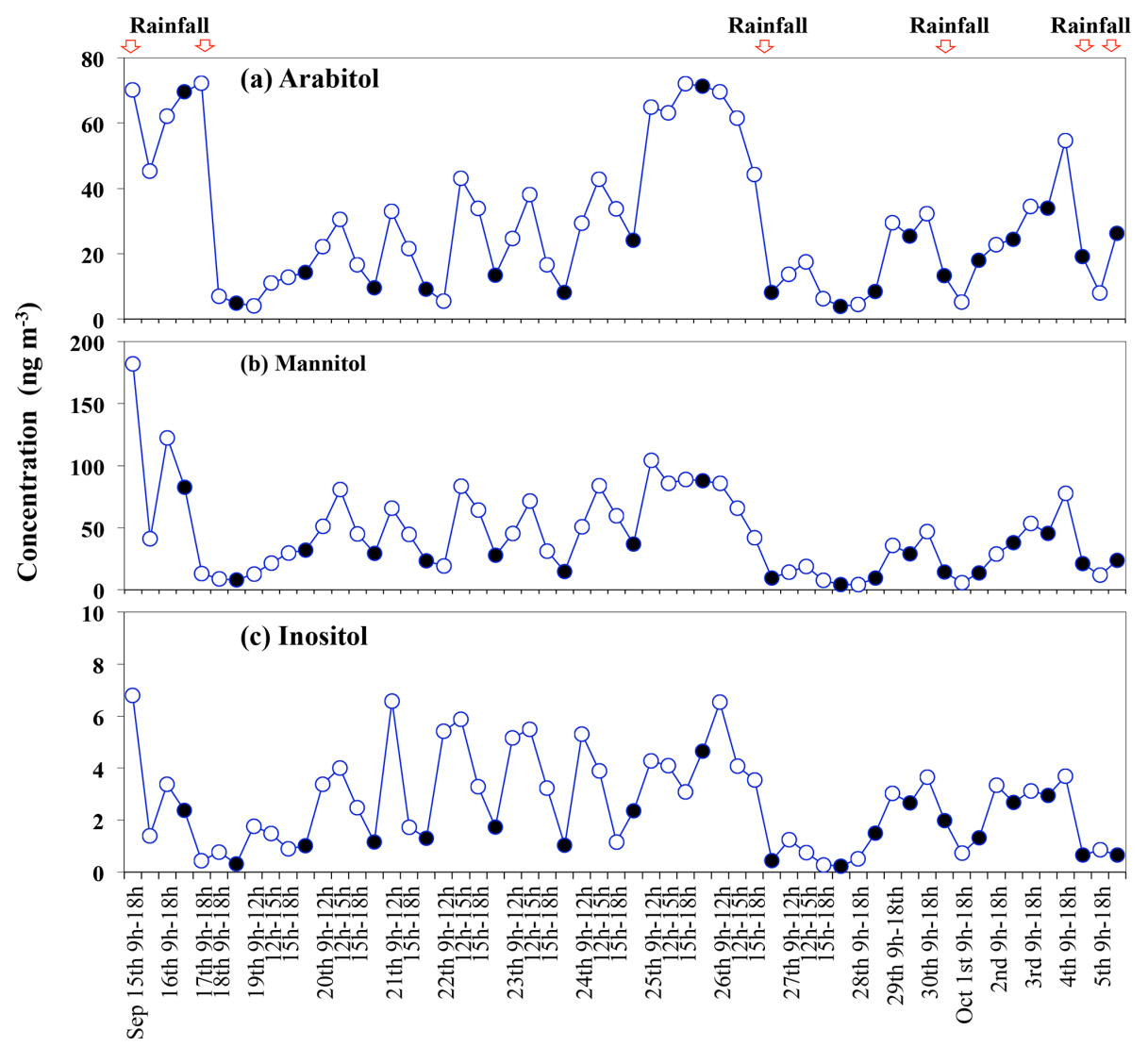

Figure 6. Temporal variations in the concentrations $\left(\mathrm{ng} \mathrm{m}^{-3}\right)$ of sugar alcohols in the Mangshan aerosol samples collected for SeptemberOctober 2007 (solid circle represents nighttime samples collected from 18:00 to 09:00; hollow circle represents daytime samples).

gested that the activities of the terrestrial biosphere widely affect mannitol concentrations in the air. Our PMF results also indicated the substantial contribution of mannitol for the vegetation factor $(24.8 \%)$, which supports that mannitol is attributed by vegetation from the forest area (Sect. 3.2).

In addition, the meteorological parameters, including high $\mathrm{RH}$ and temperature, affect the fungal and bacterial activities (Kim and Xiao, 2005; Sharma and Rajak, 2003). The maximum growth of fungi and bacteria was observed at $92 \% \mathrm{RH}-$ $100 \%$ RH (Ibrahim et al., 2011). Interestingly, the concentrations of arabitol and mannitol gradually increased after the end of precipitation, following the increases in ambient temperature and RH (Figs. 2a, 6a, b). Miyazaki et al. (2012) also discussed the increased contributions of arabitol and mannitol with daytime ambient temperature and solar radiation in the aerosol samples collected from the forest area. Similar temporal trends and positive linear correlations were observed between arabitol $(r=0.69)$ and mannitol $(r=0.57)$ with RH, which supports the above phenomenon for Mangshan aerosols (Table 2). Therefore, we propose that a favorable meteorological condition in autumn increases the emissions of fungal spores and fragments of forest vegetation, which may be responsible for arabitol and mannitol contributions in the Mangshan aerosols.
The diurnal variation of mannitol and arabitol were characterized by higher concentrations in the daytime (51.7 and $32.5 \mathrm{ng} \mathrm{m}^{-3}$, respectively) than nighttime (29.6 and $22.5 \mathrm{ng} \mathrm{m}^{-3}$, respectively) (Fig. 3b, c). Yamaguchi et al. (2012) reported that fungal spores and bacterial cells associated with bioaerosols could be transported long distances. The Mangshan site receives significant anthropogenic and bioaerosols from Beijing city by southerly winds. Therefore, the daytime plant activities, influenced by solar radiation and ambient temperature, and the long-range transport of fungal spores from megacities (Beijing) by southwest winds govern the diurnal variation of sugar alcohols in the Mangshan atmosphere. On the other hand, lower concentrations at nighttime can be explained by the clean air mass transport by mountain breeze from the Mangshan National Forest area.

\subsubsection{Source apportionment of SCs}

To investigate the source apportionment of SCs, positive matrix factorization (PMF) software version 5.0 (Environmental Protection Agency, USA) was used. The PMF analysis was performed for the measured aerosol samples using tracer compounds for anhydrosugars, primary sugars, and sugar alcohols. It is essential to select a suitable number of factor 
solutions in the PMF analysis. Based on the possible sources of SCs, four to six factor solutions were run in PMF model. In the four factor solutions, the SCs, including arabitol, mannitol, and trehalose, were merged in a single factor; this might underestimate the soil dust sources. In six factor solutions, the SCs, including glucose, fructose trehalose, arabitol, and mannitol, were distributed in more than four factors; the number of factor solutions according to possible sources of SCs might be overestimated. Therefore, a total of five interpretable factor solutions were characterized by the enrichment of each tracer compound to be significant to categorize the origins of individual sugars, which reproduced more than $95 \%$ of SCs.

These five factor solutions were preferred based on minimum robust and true $\mathrm{Q}$ values (goodness of fit parameters) of the base runs, which observed 3103 and 3505, respectively. In each bootstrap run, the concentrations and percentages of tracers were close to those of base-run results. The PMF results of SCs indicate a stability because no significant changes were found between $\mathrm{Q}$ values and factor profiles of $F_{\text {peak }}$ rotation runs compared with the base run. PMF results show a good correlation between the values of observed and predicted (modeled) concentrations in a scatter plot, indicating that the model fits the individual sugar species very well. These results support the perfect rationality of the source apportionment (Fig. S1). The time series plot of observed and predicted concentration (modeled) also shows that the model fits the observed data set well (Fig. S2). The time series plots of the factor solutions determined by PMF were similar to the temporal plots of the concentration of sugar species of the factor composition (Fig. S3). The numbers of factors were reduced if the pair of factors was strongly correlated. The composition of each factor was also checked; none of the pairs of factors were found with similar composition. We also investigated the change in factor profile with positive and negative values of $f_{\text {peak }}$ for the chosen solution in the PMF analysis. Figures 6 and 7 show the factor profile resolved by PMF analysis of the Mangshan aerosol samples. The percentages of each component are summed for factors 1 to 5 to be calculated as $100 \%$.

Factor 1 is characterized by the high contribution of glucose $(80.2 \%)$ followed by fructose $(69.6 \%)$, mannitol $(24.8 \%)$, and inositol (15.1\%) (Fig. 7a). Glucose and fructose are highly water soluble SCs present in the leaves and bark of plants (Graham et al., 2003). High concentrations of glucose and fructose have been reported in vascular plants and phytoplankton by Cowie and Hegdes (1984). The dominant glucose and fructose in the Mangshan aerosol samples collected in autumn are rational, as leaf senescence and decay result in both primary sugars being released into the atmosphere during the fall season. We found an excellent correlation between glucose and fructose $(r=0.94)$ in the Mangshan aerosols (Table 2), indicating the similar vegetation sources for both sugar species in autumn (Baker et al., 1998; Burshtein et al., 2011; Pacini, 2000). Higher concen-

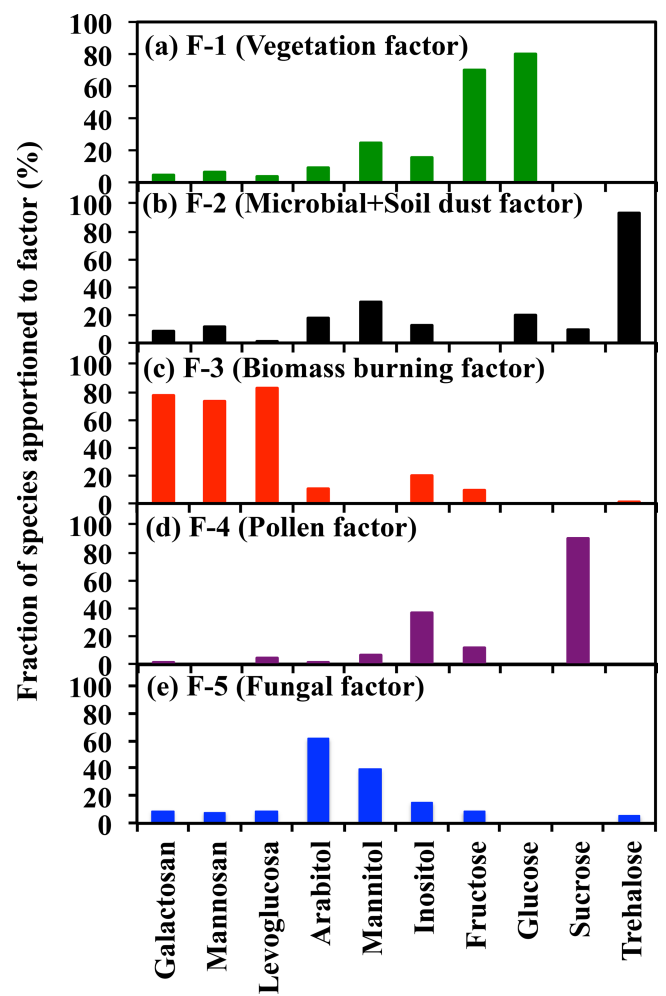

Figure 7. PMF analyses of sugar compounds in Mangshan aerosols based on the autumn 2007 data set.

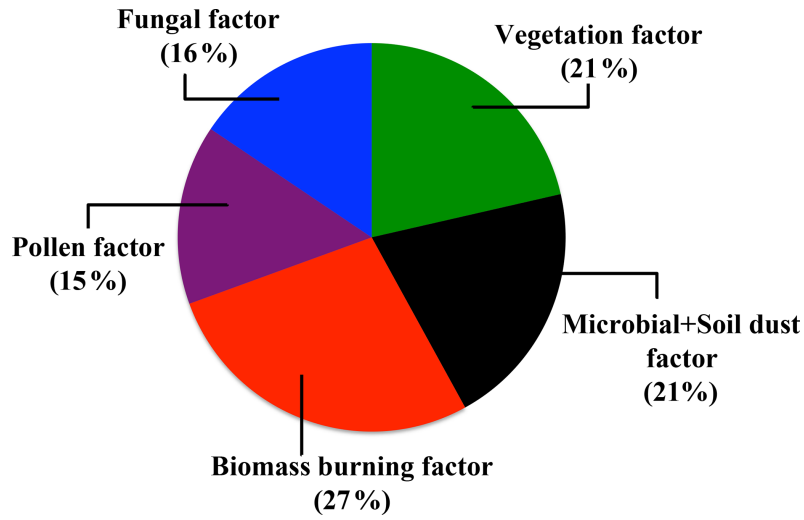

Figure 8. Source contributions to sugar compounds from various sources based on PMF analyses.

trations of glucose and fructose in the aerosol samples collected during the autumn season are reasonable because leaf senescence and decay result in an increased emission of primary sugars into the atmosphere.

Several studies have reported that plant species significantly contribute to mannitol in the atmosphere (Burshtein et al., 2011; Devis et al., 1988; 1990). Miyazaki et al. (2014) also found a significant amount of trehalose, mannitol, and arabitol in the aerosol samples collected from the forest and concluded their origin from the terrestrial plants within the 
forest. Significant positive linear correlations of mannitol with fructose in daytime $(r=0.79)$ and nighttime $(r=0.86)$ further denote that abundance of mannitol is due to the decay of plant leaves in autumn (Table 2). Therefore, we conclude that the contributions of mannitol are from both vegetation and fungal spores in the Mangshan aerosol samples. Hence mannitol showed the presence in factor 1. Vegetation contributes to SCs during the campaign. Therefore, factor 1 can be termed as a vegetation factor due to the high abundances of glucose, fructose, and mannitol.

Factor 2 is dominated by high loading of trehalose $(80.2 \%)$, followed by mannitol $(29.7 \%)$, glucose $(19.8 \%)$, and arabitol (18.2\%) (Fig. 7b). The contribution of trehalose to soil dust has been reported in several studies from different locations around the world, suggesting trehalose as a tracer for the surface soil (Jia et al., 2010; Medeiros et al., 2006). In addition, previous studies reported that bacteria and other microbes in the soil are also an essential source of trehalose (Rogge et al., 2007). Trehalose is significantly correlated with arabitol $(r=0.58)$, mannitol $(r=0.58)$, and $\mathrm{Ca}^{2+}$ $(r=0.70)$, demonstrating its microbial and soil dust origin. Therefore, factor 2 can be termed as microbial and soil dust factor.

Factor 3 is characterized by levoglucosan $(82.2 \%)$, galactosan $(77 \%)$, and mannosan $(73.6 \%)$ (Fig. 7c). Previous studies have reported that these SCs are associated with BB aerosols (Fraser and Lakshmanan, 2000; Graham et al., 2002; Simoneit, 2002). Simoneit et al. (1999) reported that the pyrolysis of cellulose and hemicellulose emitted levoglucosan, galactosan, and mannosan. These sugar species are major organic component emissions in the atmosphere by BB activities (Simoneit et al., 2002). The BB-influenced aerosols are enriched with levoglucosan, mannosan, and galactosan (Nolte et al., 2001; Medeiros et al., 2006). The domestic BB for cooking and house heating due to low ambient temperature and field burning of agricultural residues occurs in East Asia (Verma et al., 2015). The PMF results are very well supported by the fact that anhydrosugars are associated with BB (Simoneit et al., 1999). Therefore, factor 3 can be termed as a BB factor due to the high abundance of BB products.

Factor 4 is dominated by high loading of sucrose (90\%), followed by inositol (36.9\%) and fructose (11.7\%) (Fig. 7d). Sucrose plays a crucial role in the plant blossoming process as the dominant sugar compound of pollen grains (Pacini, 2000). Several studies also reported that sucrose is an abundant sugar species found in airborne pollen grains and flowering plants (Fu et al., 2012; Graham et al., 2003; Medeiros et al., 2006; Pacini, 2000). Therefore, sucrose is reported as an excellent tracer for airborne pollen spores (Pacini, 2000). Thus factor 4 is termed as pollen factor due to the high loading of sucrose.

Factor 5 is characterized by a higher contribution of arabitol $(61.5 \%)$, followed by mannitol $(39.3 \%)$ and inositol $(15.3 \%)$ (Fig. 7e). Sugar species contributing to factor 5 are associated with fungal spores (Bauer et al., 2008). Various fungi and microbes emit spores, which are tracers for the arabitol and mannitol; therefore, both sugars are considered to be specific tracers of fungal activities (Medeiros et al., 2006; Rogge et al., 2007). Thus, factor 5 is termed as a fungal factor due to the high loading of arabitol and mannitol. Overall, the average contributions of each factor to measured SCs were estimated by PMF analyses (Fig. 8), in which BB was found to account for $27 \%$ of measured SCs. The vegetation and microbial and soil dust sources equally contribute $(21 \%)$ to total SCs. The fungal spores and pollen spores contribute $16 \%$ and $15 \%$ of total SCs, respectively. Finally, biomass burning emissions from the local areas and megacities via long-range atmospheric transport were identified as an important source for the Mangshan aerosols.

\subsubsection{Contributions of sugar compounds to WSOC and OC}

The contribution of carbon content of measured SCs varied from $14.1-371 \mathrm{ng} \mathrm{m}^{-3}$ (avg. $145 \mathrm{ng} \mathrm{m}^{-3}$ ) in daytime and 12.8-322 $\mathrm{ng} \mathrm{m}^{-3}$ (avg. $117 \mathrm{ng} \mathrm{m}^{-3}$ ) at nighttime, accounting for $0.83 \%$ and $0.91 \%$ of OC, respectively (Fig. 9a, b). The mean carbon contents of anhydrosugars showed clear diurnal variation with higher nighttime values $\left(67.1 \mathrm{ng} \mathrm{m}^{-3}\right)$ than daytime $\left(42.7 \mathrm{ng} \mathrm{m}^{-3}\right)$, accounting for $0.43 \%$ and $0.22 \%$ of $\mathrm{OC}$, respectively. These results suggest that BB significantly contributed to Mangshan aerosols. However, the carbon contents of primary sugars showed opposite diurnal variations - higher $\left(68.5 \mathrm{ng} \mathrm{m}^{-3}\right)$ in daytime than nighttime $\left(28.3 \mathrm{ng} \mathrm{m}^{-3}\right.$ ), accounting for $0.41 \%$ and $0.28 \%$ of OC, respectively (Fig. 9a, b). This study suggests that the daytime emissions of primary sugars from local vegetation and the decay of plant leaf in forest significantly contribute to OC. The carbon concentration contributed by sugar alcohols showed insignificant diurnal variations, i.e., $34.6 \mathrm{ng} \mathrm{m}^{-3}$ in daytime and $21.3 \mathrm{ng} \mathrm{m}^{-3}$ at nighttime, accounting for $0.20 \%$ and $0.19 \%$ of OC, respectively. This result indicates multiple carbon sources of sugar alcohols in day and night.

Based on the PMF analysis, we found five sources for SCs measured in Mangshan aerosols. The different tracer compounds were used to calculate carbon contents: biomass burning $\mathrm{C}$ (i.e., levoglucosan, galactosan, mannosan), vegetation $\mathrm{C}$ (glucose, fructose), fungal C (arabitol, mannitol), pollen $\mathrm{C}$ (sucrose), and microbial soil $\mathrm{C}$ (trehalose) (Fig. 9c, d). Among the five sources, biomass burning $\mathrm{C}$ was found to be the largest carbon contributor to Mangshan aerosols $(36.7 \%)$, followed by fungal $\mathrm{C}(23.7 \%)$, vegetation C (19.7\%), pollen C (14.2\%), and microbial soil C (4.84\%). Biomass burning $\mathrm{C}$ accounted for $1.38 \%$ and $0.43 \%$ at night, while it was $0.57 \%$ and $0.22 \%$ in daytime for WSOC and $\mathrm{OC}$, respectively. The $\mathrm{BB}$ for cooking and space heating in winter and autumn seasons is common in central China (Akagi et al., 2011), which should increase the nighttime levels of biomass burning $\mathrm{C}$ at the Mangshan site. However, the carbon contribution by vegetation and fungal sources are 


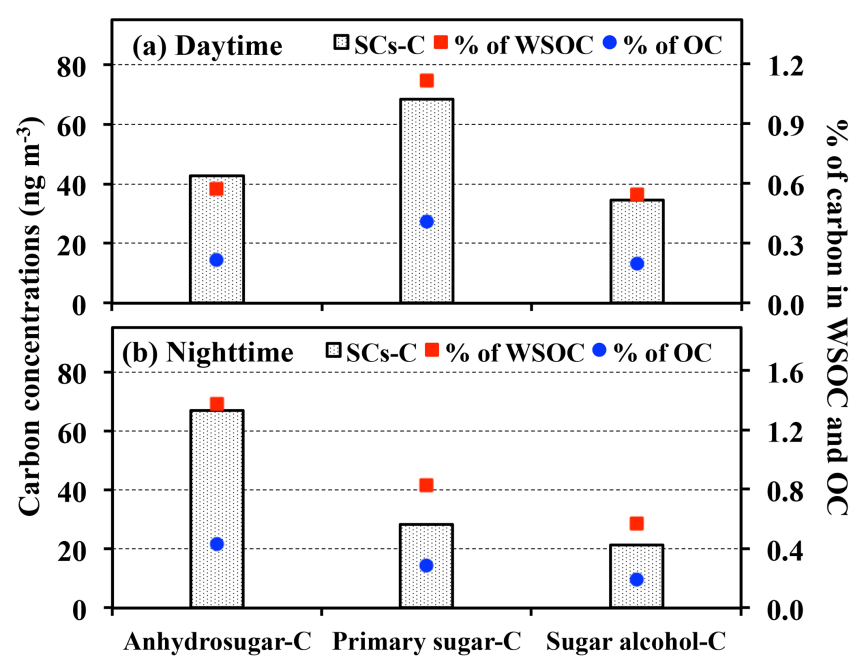

Sugar compounds

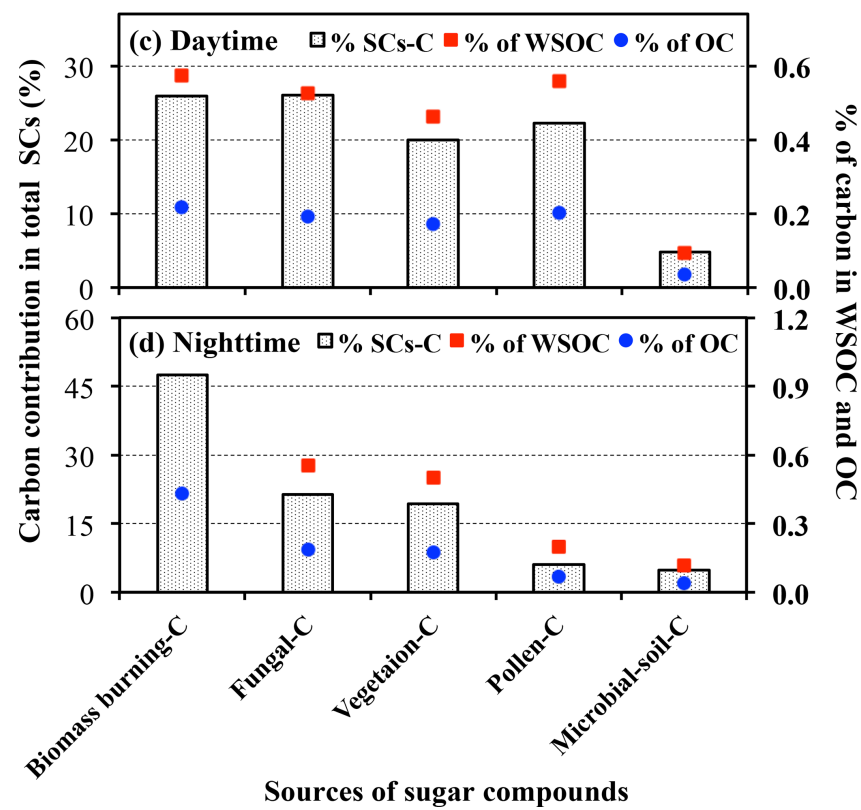

Figure 9. The concentrations and relative contributions of the carbon content of anhydrosugars, primary sugars, and sugar alcohols to the carbon concentrations of measured sugar compounds, watersoluble organic carbon (WSOC) fraction, and organic carbon (OC) fraction of Mangshan aerosols (a: daytime; b: nighttime). The concentrations and relative contribution of the carbon content of five sources of sugar compounds to total sugar compounds measured, WSOC fraction, and OC fraction of Mangshan aerosols (c: daytime; d: nighttime).

similar during day and nighttime for the Mangshan aerosols. Pollen C accounted for $0.20 \%$ and $0.07 \%$ of OC in daytime and nighttime, respectively. Higher pollen activities are key sources for the high daytime levels of pollen $\mathrm{C}$ in the forest site (Taylor et al., 2002).

\subsection{Contribution of levoglucosan to OC and WSOC}

We calculated the mass concentration ratios of levoglucosan to OC (Lev / OC) and WSOC (Lev / WSOC) to evaluate the contributions of BB and anthropogenic emissions to Mangshan aerosols (Fig. 9a-c). Fossil fuel combustion and BB emit WSOC and OC. They are also secondarily produced by photochemical oxidation of volatile organic compounds in the atmosphere (Wang et al., 2005; Deshmukh et al., 2019b). Coal combustion and vehicle exhaust can contribute to the high levels of OC and WSOC in aerosols (Xu et al., 2020). Levoglucosan, a dominant constituent of BB products, has been considered to be an excellent tracer of BB (Simoneit, 2002; Kuo et al., 2011).

The average Lev / OC ratio $\left(5.69 \times 10^{-3}\right)$ was lower than that of Lev / WSOC $\left(1.66 \times 10^{-2}\right)$ in Mangshan samples (Fig. 10a). Yan et al. (2018) reported similar ratios of Lev / OC $\left(4.0 \times 10^{-3}\right)$ and Lev / WSOC $\left(1.6 \times 10^{-2}\right)$ for coal combustion, suggesting a significant carbon contribution to Mangshan aerosols from coal combustions in the industrial areas via long-range transport. Interestingly, we found a substantial diurnal variation of Lev / OC and Lev / WSOC ratios. The average Lev / OC and Lev / WSOC ratios are several times higher at nighttime $\left(8.48 \times 10^{-3}\right.$ and $2.70 \times 10^{-2}$, respectively) than daytime $\left(4.21 \times 10^{-3}\right.$ and $1.11 \times 10^{-2}$, respectively) (Fig. 10b, c). These results indicate that BB contributed substantially to the Mangshan organic aerosols at nighttime. Moreover, the correlations of levoglucosan with OC and WSOC are stronger at nighttime $(r=0.81$ and 0.70 , respectively) than daytime ( $r=0.45$ and 0.40 , respectively), demonstrating the dominance of BB-derived aerosols in the nighttime Mangshan samples (Table 2).

In addition, WSOCs are derived from various emission sources. We propose that secondary organic aerosols constitute a significant fraction of WSOC and OC in daytime Mangshan aerosols. The photochemical oxidation of organic precursors emitted from fossil fuel combustion in industries and vehicular exhausts also contributes to secondary production of WSOC and OC in daytime (He et al., 2015), suggesting that emissions from the urban Beijing area may significantly influence the daytime levels of Mangshan aerosols. He et al. (2015) proposed a possible contribution of photochemical formation of secondary organic aerosols to atmospheric WSOC and OC in north China. Nevertheless, the photochemical degradation of levoglucosan by $\mathrm{OH}$ radicals under ultraviolet radiation and high temperatures (Hennigan et al., 2010) may play a key role in lowering the ratios of Lev / OC and Lev / WSOC in daytime Mangshan aerosols.

\subsection{Mass concentration ratios of levoglucosan / mannosan}

The mass concentration ratios of levoglucosan and mannosan (Lev / Man) were calculated to better characterize the emissions sources of BB tracers (softwood vs. hardwood) 


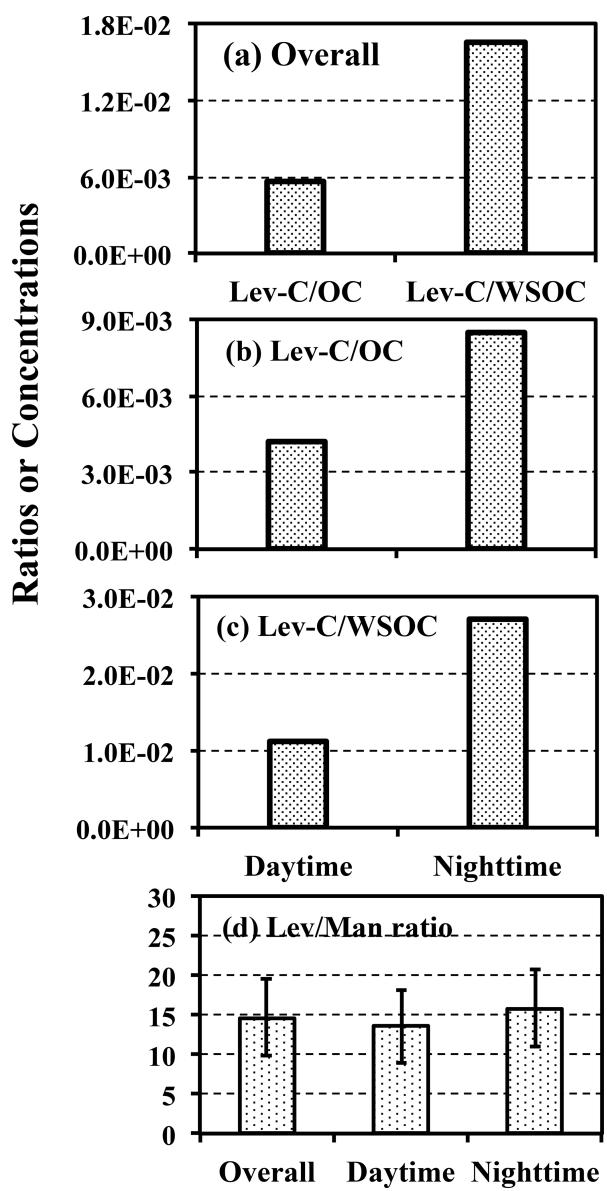

Figure 10. Mass concentration ratio of carbon contents of (a) levoglucosan (Lev) to organic carbon (OC) and water-soluble organic carbon (WSOC), (b) levoglucosan (Lev) to organic carbon (OC) daytime and nighttime, (c) levoglucosan (Lev) to water-soluble organic carbon (WSOC) daytime and nighttime, and (d) average levoglucosan-to-mannosan ratios (Lev / Man) in the Mangshan aerosol samples for autumn 2007.

in the Mangshan site. Figure 10d represents the variations of Lev / Man ratios for overall, daytime, and nighttime periods. The Lev / Man ratios have been used to distinguish the hardwood (angiosperm) and softwood (gymnosperm) burning in the ice core record from the Russian Far East (Kawamura et al., 2012). Hardwood contains $55 \%-65 \%$ cellulose and 20\%-30\% hemicellulose (Klemm et al., 2005). Levoglucosan and mannosan are derived from the thermal decomposition of cellulose and hemicelluloses, respectively (Simoneit, 2002). Levoglucosan is thermally more stable than mannosan and galactosan (Kuo et al., 2011). Hence, a lower Lev / Man ratio is associated with softwood burning, whereas a higher ratio is associated with hardwood burning (Engling et al., 2006, 2009). However, we found insignificant diurnal variations of Lev / Man ratios between night (9.3325.9, avg. 15.8) and daytime aerosols (0.90-23.3, avg. 13.6). Likewise, comparable Lev / Man ratios (9-13 for $\mathrm{PM}_{10}$ and
10-13 for $\mathrm{PM}_{2.5}$ ) were reported for aerosol samples from Tanzania, where wood and charcoal are primary fuels used for domestic cooking and heating (Mkoma and Kawamura, 2013). Interestingly, wheat straws and lignite are used in China for domestic cooking and house heating, which may also contribute to levoglucosan and mannosan in the Mangshan aerosols.

Different Lev / Man ratios were reported in the chamber and controlled field experiments, e.g., 4-22 for conifer and savanna grass burning (Iinuma et al., 2007) as well as 41.6 for rice straw and 55.7 for cereal straw burning (Engling et al., 2009; Zhang et al., 2007). Kuo et al. (2011) reported higher emissions of levoglucosan during high-temperature flaming (27.5-52.3) compared to low-temperature smoldering (2.433.08). Hence, it is not easy to differentiate hardwood and softwood burning based on Lev / Man ratios alone. Several studies reported a high Lev / Man ratio for both softwood and hardwood burning. Thus, there may exist some other factors that significantly control the Lev / Man ratios. Yan et al. (2018) found a significant contribution of levoglucosan in coal combustion with a Lev / Man ratio of 7.2. The variations of Lev / Man ratios in Mangshan may be significantly influenced by several factors, i.e., flaming vs. smoldering, duration of biomass burning, coal combustion, and hardwood vs. softwood burning. The moderate Lev / Man ratios in autumn aerosols from Mangshan suggest that low-temperature smoldering processes of hardwood contribute to levels of levoglucosan and mannosan. However, the contribution of coal combustions for house heating could not be excluded.

\section{Summary and conclusions}

Anhydrosugars, primary sugars, and sugar alcohols were detected with distinct diurnal variations in suburban aerosol samples collected at the Mangshan site in the northern vicinity of Beijing. The wind patterns indicate that daytime air masses were transported from urban Beijing to Mangshan, while clean air masses were delivered at nighttime from the Mangshan National Forest Park. Daytime air masses from urban Beijing significantly influence the air quality of the northern forest region. We observed the highest abundance of primary sugars, followed by anhydrosugars and sugar alcohols. Local emissions from the forest plants and fungal species are the main contributors to the primary sugars and sugar alcohols in the Mangshan aerosols. The meteorological parameter significantly influenced the levels of SCs in the Mangshan samples. We observed a significant influence of enhanced ambient temperature and solar radiation on the pollen rupture and increased $\mathrm{RH}$ on fungal and microbial growth. This study suggested the source variation for trehalose, i.e., local microbes at night and soil dust particles transported from Beijing areas by southerly wind in daytime. We found that vegetation and fungal spores are not a spe- 
cific source of glucose and mannitol, respectively. Both sugars may have multiple sources in the forest aerosols.

PMF results concluded the contributions of $36 \%$ from vegetation $(21 \%$ vegetation factor and $15 \%$ pollen factor) and $37 \%$ from microbial and fungal species (21\% microbial soil dust and $16 \%$ fungal factor) of total measured SCs. The BB activities for domestic cooking and space heating in north China contributed higher organic carbon at nighttime $(0.43 \%)$ than in daytime $(0.22 \%)$. Therefore, local BB seriously affected the air quality of the Mangshan site. Lev / Man ratio suggested that low-temperature smoldering burning of hardwood is the main source for BB aerosols. SCs were recognized as a significant aerosol component at Mangshan, northern suburbs of Beijing. SCs can influence the air quality and thus climate because they are essential components of organic aerosols on a global scale. This study of SCs at Mangshan demonstrates that ambient levels of SCs are highly sensitive to the emissions of anthropogenic and biogenic aerosols. Higher contribution of levoglucosan to SCs demonstrated a significant BB activity around the Mangshan site in north China.

Data availability. Raw data are available on request by contacting the corresponding author.

Supplement. The supplement related to this article is available online at: https://doi.org/10.5194/acp-21-4959-2021-supplement.

Author contributions. This research was designed YK, KK, and ZW. Laboratory measurements were performed by FY with the support of PF. The paper was prepared by SKV and KK.

Competing interests. The authors declare that they have no conflict of interest.

Acknowledgements. The authors thank Kazuhiko Okuzawa for his help during the sample collection. This study was partly supported by the National Natural Science Foundation of China through grantin-aid no. 41625014. The financial support by the Global Environment Research Fund (B-051) of the Ministry of the Environment, Japan, is also acknowledged for the shipping of the sampling equipment to the Mangshan site.

Financial support. This research was supported by the Japan Society for the Promotion of Science (JSPS) through grant-in-aid nos. 19204055 and 24221001.

Review statement. This paper was edited by Lynn M. Russell and reviewed by two anonymous referees.

\section{References}

Akagi, S. K., Yokelson, R. J., Wiedinmyer, C., Alvarado, M. J., Reid, J. S., Karl, T., Crounse, J. D., and Wennberg, P. O.: Emission factors for open and domestic biomass burning for use in atmospheric models, Atmos. Chem. Phys., 11, 4039-4072, https://doi.org/10.5194/acp-11-4039-2011, 2011.

Baker, H. G., Baker, I., and Hodges, S. A.: Sugar composition of nectars and fruits consumed by birds and bats in the tropics and subtropics, Biotropica, 30, 559-586, https://doi.org/10.1111/j.1744-7429.1998.tb00097.x, 1998.

Bauer, H., Schueller, E., Weinke, G., Berger, A., Hitzenberger, R., Marr, I. L., and Puxbaum, H.: Significant contributions of fungal spores to the organic carbon and to the aerosol mass balance of the urban atmospheric aerosol, Atmos. Environ., 42, 5542-5549, https://doi.org/10.1016/j.atmosenv.2008.03.019, 2008.

Bieleski, R. L.: Onset of phloem export from senescent petals of Daylily, Plant Physiol., 109, 557-565, https://doi.org/10.1104/pp.109.2.557, 1995.

Brown, J. K. M. and Hovmoller, M. S.: Epidemiology - Aerial dispersal of pathogens on the global and continental scales and its impact on plant disease, Science, 297, 537-541, https://doi.org/10.1126/science.1072678, 2002.

Burshtein, N., Lang-Yona, N., and Rudich, Y.: Ergosterol, arabitol and mannitol as tracers for biogenic aerosols in the eastern Mediterranean, Atmos. Chem. Phys., 11, 829-839, https://doi.org/10.5194/acp-11-829-2011, 2011.

Cao, C., Jiang, W., Wang, B., Fang, J., Lang, J., Tian, G., Jiang, J. K., and Zhu, T. F.: Inhalable microorganisms in Beijing's $\mathrm{PM}_{2.5}$ and $\mathrm{PM}_{10}$ pollutants during a severe smog event, Environ. Sci. Technol., 48, 1499-1507, https://doi.org/10.1021/es4048472, 2014.

Carvalho, A., Pio, C., and Santos, C.: Water-soluble hydroxylated organic compounds in German and Finnish aerosols, Atmos. Environ., 37, 1775-1783, https://doi.org/10.1016/S13522310(03)00066-9, 2003.

Claeys, M., Graham, B., Vas, G., Wang, W., Vermeylen, R., Pashynska, V., Cafmeyer, J., Guyon, P., Andreae, M. O., Artaxo, P., and Maenhaut, W.: Formation of secondary organic aerosols through photooxidation of isoprene, Science, 303, 1173-1176, https://doi.org/10.1126/science.1092805, 2004.

Cooke, W.F., Liousse, C., Cachier, H., and Feichter, J.: Construction of a $1^{\circ} \times 1^{\circ}$ fossil fuel emission data set for carbonaceous aerosol and implementation and radiative impact in the ECHAM4 model, J. Geophys. Res.-Atmos., 104, 22137-22162, https://doi.org/10.1029/1999JD900187, 1999.

Cowie, G. L. and Hedges, J. I.: Carbohydrate sources in a coastal marine-environment, Geochim. Cosmochim. Ac., 48, 20752087, https://doi.org/10.1016/0016-7037(84)90388-0, 1984.

Dahlman, L., Persson, J., Nasholm, T., and Palmqvist, K.: Carbon and nitrogen distribution in the green algal lichens Hypogymnia physodes and Platismatia glauca in relation to nutrient supply, Planta, 217, 41-48, https://doi.org/10.1007/s00425-003-0977-8, 2003.

Davis, J. M. and Loescher, W. H.: $\left[{ }^{14} \mathrm{C}\right]$-Assimilate translocation in the light and dark in celery (Apium graveokns) leaves of different ages, Physiol. Plant, 79, 656-662, https://doi.org/10.1111/j.1399-3054.1990.tb00040.x, 1990.

Davis, J. M., Fellman, J. K., and Loescher, W. H.: Biosynthesis of sucrose and mannitol as a function of leaf age in 
celery (Apiulm graveolens L.), Plant Physio., 186, 129-133, https://doi.org/10.1104/pp.86.1.129, 1988.

Deshmukh, D. K., Haque, M. M., Kim, Y., and Kawamura, K.: Organic tracers of fine aerosol particles in central Alaska: summertime composition and sources, Atmos. Chem. Phys., 19, 1400914029, https://doi.org/10.5194/acp-19-14009-2019, 2019a.

Deshmukh, D. K., Kawamura, K., Gupta, T., Haque, M. M., Zhang, Y. L., Singh, D. K., and Tsai, Y. I.: High loadings of watersoluble oxalic acid and related compounds in $\mathrm{PM}_{2.5}$ aerosols in Eastern Central India: influence of biomass burning and photochemical processing, Aerosol Air Qual. Res., 19, 2625-2644, https://doi.org/10.4209/aaqr.2019.10.0543, 2019b.

Després, V. R., Huffman, J. A., Burrows, S. M., Hoose, C., Safatov, A. S., Buryak, G., Fröhlich-Nowoisky, J., Elbert, W., Andreae, M. O., Pöschl, U., and Jaenicke, R.: Primary biological aerosol particles in the atmosphere: a review, Tellus B, 64, 15598, https://doi.org/10.3402/tellusb.v64i0.15598, 2012.

Elbert, W., Taylor, P. E., Andreae, M. O., and Pöschl, U.: Contribution of fungi to primary biogenic aerosols in the atmosphere: wet and dry discharged spores, carbohydrates, and inorganic ions, Atmos. Chem. Phys., 7, 4569-4588, https://doi.org/10.5194/acp-74569-2007, 2007.

Engling, G., Carrico, C. M., Kreidenweis, S. M., Collett, J. L., Day, D. E., Malm, W. C., Lincoln, E., Hao, W. M., Iinuma, Y., and Herrmann, H.: Determination of levoglucosan in biomass combustion aerosol by highperformance anion-exchange chromatography with pulsed amperometric detection, Atmos. Environ., 40, S299-S311, https://doi.org/10.1016/j.atmosenv.2005.12.069, 2006.

Engling, G., Lee, J. J., Tsai, Y. W., Lung, S. C. C., Chou, C. C. K., and Chan, C. Y.: Size-resolved anhydrosugar composition in smoke aerosol from controlled field burning of rice straw, Aerosol Sci. Tech., 43, 662-672, https://doi.org/10.1080/02786820902825113, 2009.

Filippo, P. D., Pomata, D., Riccardi, C., Buiarelli, F., and Perrino, C.: Fungal contribution to size-segregated aerosol measured through biomarkers, Atmos. Environ., 64, 132-140, https://doi.org/10.1016/j.atmosenv.2012.10.010, 2013.

Fraser, M. P. and Lakshmanan, K.: Using levoglucosan as a molecular marker for the long-range transport of biomass combustion aerosols, Environ. Sci. Technol., 34, 4560-4564, https://doi.org/10.1021/es9912291, 2000.

Fu, P. Q., Kawamura, K., Okuzawa, K., Aggarwal, S. G., Wang, G. H., Kanaya, Y., and Wang, Z. F.: Organic molecular compositions and temporal variations of summertime mountain aerosols over Mt. Tai, North China Plain, J. Geophys. Res.-Atmos., 113, D19107, https://doi.org/10.1029/2008jd009900, 2008.

Fu, P. Q., Kawamura, K., Pavuluri, C. M., Swaminathan, T., and Chen, J.: Molecular characterization of urban organic aerosol in tropical India: contributions of primary emissions and secondary photooxidation, Atmos. Chem. Phys., 10, 2663-2689, https://doi.org/10.5194/acp-10-2663-2010, 2010.

Fu, P. Q., Kawamura, K., Kobayashi, M., and Simoneit, B. R. T.: Seasonal variations of sugars in atmospheric particulate matter from Gosan, Jeju Island: Significant contributions of airborne pollen and Asian dust in spring, Atmos. Environ., 55, 234-239, https://doi.org/10.1016/j.atmosenv.2012.02.061, 2012.

Fuzzi, S., Decesari, S., Facchini, M. C., Cavalli, F., Emblico, L., Mircea, M., Andreae, M. O., Trebs, I., Hoffer, A., Guyon, P.,
Artaxo, P., Rizzo, L. V., Lara, L. L., Pauliquevis, T., Maenhaut, W., Raes, N., Chi, X. G., Mayol-Bracero, O. L., SotoGarcia, L. L., Claeys, M., Kourtchev, I., Rissler, J., Swietlicki, E., Tagliavini, E., Schkolnik, G., Falkovich, A. H., Rudich, Y., Fisch, G., and Gatti, L. V.: Overview of the inorganic and organic composition of size-segregated aerosol in Rondonia, Brazil, from the biomass-burning period to the onset of the wet season, J. Geophys. Res.-Atmos., 112, D01201, https://doi.org/10.1029/2005jd006741, 2007.

Graham, B., Mayol-Bracero, O. L., Guyon, P., Roberts, G. C., Decesari, S., Facchini, M. C., Artaxo, P., Maenhaut, W., Koll, P., and Andreae, M. O.: Water-soluble organic compounds in biomass burning aerosols over Amazonia 1. Characterization by NMR and GC-MS, J. Geophys. Res., 107, 8047, https://doi.org/10.1029/2001JD000336, 2002.

Graham, B., Guyon, P., Taylor, P. E., Artaxo, P., Maenhaut, W., Glovsky, M. M., Flagan, R. C., and Andreae, M. O.: Organic compounds present in the natural Amazonian aerosol: Characterization by gas chromatography-mass spectrometry, J. Geophys. Res.-Atmos., 108, 4766, https://doi.org/10.1029/2003jd003990, 2003.

Hackl, E., Bachmann, G., and Zechmeister-Boltenstern, S.: Soil microbial biomass and rhizosphere effects in natural forest stands, Phyton.-Ann. Rei. Bot. A, 40, 83-90, 2000.

Han, F., Kota, S. H., Wang, Y., and Zhang, H.: Source apportionment of $\mathrm{PM}_{2.5}$ in Baton Rouge, Louisiana during 2009-2014, Sci. Total Environ., 586, 115-126. https://doi.org/10.1016/j.scitotenv.2017.01.189, 2017.

He, N., Kawamura, K., Kanaya, Y., and Wang, Z.: Diurnal variations of carbonaceous components, major ions, and stable carbon and nitrogen isotope ratios in suburban aerosols from northern vicinity of Beijing, Atmos. Environ., 123, 18-24, https://doi.org/10.1016/j.atmosenv.2015.10.052, 2014.

He, N., Kawamura, K., Kanaya, Y., and Wang, Z. F.: Diurnal variations of carbonaceous components, major ions, and stable carbon and nitrogen isotope ratios in suburban aerosols from northern vicinity of Beijing, Atmos. Environ., 123, 18-24, https://doi.org/10.1016/j.atmosenv.2015.10.052, 2015.

Heald, C. L. and Spracklen, D. V.: Atmospheric budget of primary biological aerosol particles from fungal spores, Geophys. Res. Lett., 36, L09806, https://doi.org/10.1029/2009GL037493, 2009.

Hennigan, C. J., Sullivan, A. P., Collett Jr., J. L., and Robinson, A. L.: Levoglucosan stability in biomass burning particles exposed to hydroxyl radicals, Geophys. Res. Lett., 37, L09806, https://doi.org/10.1029/2010g1043088, 2010.

Ibrahim, M., Rabah, A. B., Liman, B., and Ibrahim, N. T.: Effect of temperature and relative humidity on the growth of Helminthosporium fulvum, Nigerian J. Basic Appli. Sci., 19, 127-129, https://doi.org/10.4314/njbas.v19i1.69357, 2011.

Iinuma, Y., Bruggemann, E., Gnauk, T., Muller, K., Andreae, M. O., Helas, G., Parmar, R., and Herrmann, H.: Source characterization of biomass burning particles: The combustion of selected European conifers, African hardwood, savanna grass, and German and Indonesian peat, J. Geophys. Res.-Atmos., 112, D08209, https://doi.org/10.1029/2006jd007120, 2007.

Jaenicke, R.: Abundance of cellular material and proteins in the atmosphere, Science, 308, 73, https://doi.org/10.1126/science.1106335, 2005. 
Jia, Y. L., Clements, A. L., and Fraser, M. P.: Saccharide composition in atmospheric particulate matter in the southwest US and estimates of source contributions, J. Aerosol Sci., 41, 62-73, https://doi.org/10.1016/j.jaerosci.2009.08.005, 2010.

Jones, E. B. G. and Mitchell, J. I.: Biodiversity of marine fungi, in biodiversity: international biodiversity seminar, edited by: Cimerman, A. and Gunde-Cimerman, N., National Inst. Chemistry and Slovenia National Commission for UNESCO, Ljubljana, 31-42, 1996.

Kanakidou, M., Seinfeld, J. H., Pandis, S. N., Barnes, I., Dentener, F. J., Facchini, M. C., Van Dingenen, R., Ervens, B., Nenes, A., Nielsen, C. J., Swietlicki, E., Putaud, J. P., Balkanski, Y., Fuzzi, S., Horth, J., Moortgat, G. K., Winterhalter, R., Myhre, C. E. L., Tsigaridis, K., Vignati, E., Stephanou, E. G., and Wilson, J.: Organic aerosol and global climate modelling: a review, Atmos. Chem. Phys., 5, 1053-1123, https://doi.org/10.5194/acp-5-10532005, 2005.

Kanaya, Y., Akimoto, H., Wang, Z.-F., Pochanart, P., Kawamura, K., Liu, Y., Li, J., Komazaki, Y., Irie, H., Pan, X.-L., Taketani, F., Yamaji, K., Tanimoto, H., Inomata, S., Kato, S., Suthawaree, J., Okuzawa, K., Wang, G., Aggarwal, S. G., Fu, P. Q., Wang, T., Gao, J., Wang, Y., and Zhuang, G.: Overview of the Mount Tai Experiment (MTX2006) in central East China in June 2006: studies of significant regional air pollution, Atmos. Chem. Phys., 13, 8265-8283, https://doi.org/10.5194/acp13-8265-2013, 2013.

Kang, M., Ren, L., Ren, H., Zhao, Y., Kawamura, K., Zhang, H., Wei, L., Sun, Y., Wang, Z., and Fu, P. Q.: Primary biogenic and anthropogenic sources of organic aerosols in Beijing, China: Insights from saccharides and $n$-alkanes, Environ. Pollut., 243, 1579-1587, https://doi.org/10.1016/j.envpol.2018.09.118, 2018.

Kawamura, K., Izawa, Y., Mochida, M., and Shiraiwa, T.: Ice core records of biomass burning tracers (levoglucosan and dehydroabietic, vanillic and p-hydroxybenzoic acids) and total organic carbon for past 300 years in the Kamchatka Peninsula, Northeast Asia, Geochim. Cosmochim. Ac., 99, 317-329, https://doi.org/10.1016/j.gca.2012.08.006, 2012.

Kawamura, K., Tachibana, E., Okuzawa, K., Aggarwal, S. G., Kanaya, Y., and Wang, Z. F.: High abundances of water-soluble dicarboxylic acids, ketocarboxylic acids and $\alpha$-dicarbonyls in the mountaintop aerosols over the North China Plain during wheat burning season, Atmos. Chem. Phys., 13, 8285-8302, https://doi.org/10.5194/acp-13-8285-2013, 2013.

Keller, F. and Matile, P.: Storage of sugars and mannitol in petioles of celery leaves, New Phytol. 113, 291-299, https://doi.org/10.1111/j.1469-8137.1989.tb02406.x, 1989.

Kim, V. K. and Xiao, C. L.: Influence of culture media and environmental factors on mycelial growth and picnidial production of Sphaeropsis pyriputrescens, Mycologia, 97, 25-32, https://doi.org/10.3852/mycologia.97.1.25, 2005.

Klemm, D., Heublein, B., Fink, H. P., and Bohn, A.: Cellulose: Fascinating biopolymer and sustainable raw material, Angew. Chem. Int. Ed., 44, 3358-3393, https://doi.org/10.1002/anie.200460587, 2005.

Kuo, L. J., Louchouarn, P., and Herbert, B. E.: Influence of combustion conditions on yields of solvent-extractable anhydrosugars and lignin phenols in chars: Implications for characterizations of biomass combustion residues, Chemosphere, 85, 797805, https://doi.org/10.1016/j.chemosphere.2011.06.074, 2011.
Lelieveld, J., Evans, J. S., Fnais, M., Giannadaki, D., and Pozzer, A.: The contribution of outdoor air pollution sources to premature mortality on a global scale, Nature, 525, 367-371, https://doi.org/10.1038/nature15371, 2015.

Lewis, D. and Smith, D.: Sugar alcohols (polyols) in fungi and green plants, 1. Distribution, physiology and metabolism, New Phytol., 66, 143-184, https://doi.org/10.1111/j.14698137.1967.tb05997.x, 1967.

Li, W. J., Shao, L. Y., and Buseck, P. R.: Haze types in Beijing and the influence of agricultural biomass burning, Atmos. Chem. Phys., 10, 8119-8130, https://doi.org/10.5194/acp-108119-2010, 2010.

Lin, J., Pan, D., Davis, S. J., Zhang, Q., He, K., Wang, C., Streets, D. G., Wuebbles, D. J., and Guan, D.: China's international trade and air pollution in the United States, P. Natl. Acad. Sci. USA, 111, 1736-1741, https://doi.org/10.1073/pnas.1312860111, 2014.

Loescher, W. H., Tyson, R. H., Everard, J. D., Redgwell, R. J., and Bieleski, R. L.: Mannitol synthesis in higher plants: evidence for the role and characterization of a NADPH-Dependent mannose 6-Phosphate reductase, Plant Physiol., 98, 1396-1402, https://doi.org/10.1104/pp.98.4.1396, 1992.

Malik, V. K. and Singh, S.: Effect of temperature and relative humidity on teliospore germination in Ustilago hordei, J. Mycol. Plant Pathol., 34, 410-411, https://doi.org/10.4314/njbas.v19i1.69357, 2004.

Manninen, H. E., Bäck, J., Sihto Nissila, S. L., Huffman, J. A., Pessi, A. M., Hiltunen, V., Aalto, P. P., Hidalgo Fernaìndez, P. J., Hari, P., and Saarto, A.: Patterns in airborne pollen and other primary biological aerosol particles (PBAP), and their contribution to aerosol mass and number in a boreal forest, Boreal Environ. Res., 19, 383-405, 2014.

Medeiros, P. M., Conte, M. H., Weber, J. C., and Simoneit, B. R. T.: Sugars as source indicators of biogenic organic carbon in aerosols collected above the Howland Experimental Forest, Maine, Atmos. Environ., 40, 1694-1705, https://doi.org/10.1016/j.atmosenv.2005.11.001, 2006.

Miyazaki, Y., Jung, J., Fu, P. Q., Mizoguchi, Y., Yamanoi, K., and Kawamura, K.: Evidence of formation of submicrometer water-soluble organic aerosols at a deciduous forest site in northern Japan in summer, J. Geophys. Res., 117, D19213, https://doi.org/10.1029/2012JD018250, 2012.

Miyazaki, Y., Fu., P. Q., Ono, K., Tachibana, E., and Kawamura, K.: Seasonal cycles of water-soluble organic nitrogen aerosols in a deciduous broadleaf forest in northern Japan, J. Geophys. Res.-Atmos., 119, 1440-1454, https://doi.org/10.1002/2013JD020713, 2014.

Mkoma, S. L. and Kawamura, K.: Molecular composition of dicarboxylic acids, ketocarboxylic acids, $\alpha$-dicarbonyls and fatty acids in atmospheric aerosols from Tanzania, East Africa during wet and dry seasons, Atmos. Chem. Phys., 13, 2235-2251, https://doi.org/10.5194/acp-13-2235-2013, 2013.

Nolte, C. G., Schauer, J. J., Cass, G. R., and Simoneit, B. R. T.: Highly polar organic compounds present in wood smoke and in the ambient atmosphere, Environ. Sci. Technol., 35, 1912-1919, https://doi.org/10.1021/es001420r, 2001.

Paatero, P. and Tapper, U.: Positive matrix factorization a nonnegative factor model with optimal utilization of 
error-estimates of data values, Environmetrics, 5, 111-126, https://doi.org/10.1002/env.3170050203, 1994.

Paatero, P., Hopke, P. K., Song, X. H., and Ramadan, Z.: Understanding and controlling rotations in factor analytic models, Chemom. Intell. Lab. Syst., 60, 253-264, https://doi.org/10.1016/S0169-7439(01)00200-3, 2002.

Pacini, E.: From anther and pollen ripening to pollen presentation, Plant Syst. Evol., 222, 19-43, https://doi.org/10.1007/BF00984094, 2000.

Pashynska, V., Vermeylen, R., Vas, G., Maenhaut, W., and Claeys, M.: Development of a gas chromatographic/ion trap mass spectrometric method for the determination of levoglucosan and saccharidic compounds in atmospheric aerosols. Application to urban aerosols, J. Mass Spectrom., 37, 1249-1257, https://doi.org/10.1002/jms.391, 2002.

Qiao, X., Ying, Q., Li, X., Zhang, H., Hu, J., Tang, Y., and Chen, X.: Source apportionment of $\mathrm{PM}_{2.5}$ for 25 Chinese provincial capitals and municipalities using a source-oriented community multiscale air quality model, Sci. Total Environ., 612, 462-471, https://doi.org/10.1016/j.scitotenv.2017.08.272, 2018.

Rogge, W. F., Medeiros, P. M., and Simoneit, B. R. T.: Organic marker compounds in surface soils of crop fields from the San Joaquin Valley fugitive dust characterization study, Atmos. Environ., 41, 8183-8204, https://doi.org/10.1016/j.atmosenv.2007.06.030, 2007.

Rumpho, M. E., Edwards, G. E., and Loescher, W. H.: A pathway for photosynthetic carbon flow to mannitol in celery leaves. Activity and localization of key enzymes, Plant Physiol., 73, 869873, https://https://doi.org/10.1104/pp.73.4.869, 1983.

Sharma, R. and Rajak, R. C.: Keratinophilic fungi: Nature's keratin degrading machines, Resonance, 8, 28-30, https://doi.org/10.1007/BF02837919, 2003.

Simoneit, B. R. T.: Biomass burning - A review of organic tracers for smoke from incomplete combustion, Appl. Geochem., 17, 129-162, https://doi.org/10.1016/S0883-2927(01)00061-0, 2002.

Simoneit, B. R. T., Schauer, J. J., Nolte, C. G., Oros, D. R., Elias, V. O., Fraser, M. P., Rogge, W. F., and Cass, G. R.: Levoglucosan, a tracer for cellulose in biomass burning and atmospheric particles, Atmos. Environ., 33, 173-182, https://doi.org/10.1016/S13522310(98)00145-9, 1999.

Simoneit, B. R. T., Kobayashi, M., Mochida, M., Kawamura, K., Lee, M., Lim, H. J., Turpin, B. J., and Komazaki, Y.: Composition and major sources of organic compounds of aerosol particulate matter sampled during the ACE-Asia campaign, J. Geophys. Res.-Atmos., 109, D19S10, https://doi.org/10.1029/2004jd004598, 2004.

Streets, D. G., Yarber, K. F., Woo, J. H., and Carmichael, G. R.: Biomass burning in Asia: Annual and seasonal estimates and atmospheric emissions, Global Biogeochem. Cy., 17, 1099, https://doi.org/10.1029/2003GB002040, 2003.

Sullivan, A. P., Holden, A. S., Patterson, L. A., McMeeking, G. R., Kreidenweis, S. M., Malm, W. C., Hao, W. M., Wold, C. E., and Collett Jr., J. L.: A method for smoke marker measurements and its potential application for determining the contribution of biomass burning from wildfires and prescribed fires to ambient $\mathrm{PM}_{2.5}$ organic carbon, J. Geophys. Res., 113, D22302, https://doi.org/10.1029/2008JD010216, 2008.
Sun, Y., Jiang, Q., Xu, Y., Ma, Y., Zhang, Y., Liu, X., Li, W., Wang, F., Li, J., Wang, P., and Li, Z.: Aerosol characterization over the north China plain: haze life cycle and biomass burning impacts in summer, J. Geophys. Res., 121, 2508-2521, https://doi.org/10.1002/2015JD024261, 2016.

Tao, J., Zhang, L., Cao, J., and Zhang, R.: A review of current knowledge concerning PM2.5 chemical composition, aerosol optical properties and their relationships across China, Atmos. Chem. Phys., 17, 9485-9518, https://doi.org/10.5194/acp-179485-2017, 2017.

Taylor, P. E., Flagan, R. C., Valenta, R., and Glovsky, M. M.: Release of allergens as respirable aerosols: A link between grass pollen and asthma, J. Allergy Clin. Immunol., 109, 51-56, https://doi.org/10.1067/mai.2002.120759, 2002.

Verma, S. K., Kawamura, K., Chen, J., Fu, P. Q., and Zhu, C.: Thirteen years observation of biomass-burning organic tracers over Chichijima Island in the western North Pacific: An outflow region of Asian aerosols, J. Geophys. Res.-Atmos., 120, 41554168, https://doi.org/10.1002/2014JD022224, 2015.

Verma, S. K., Kawamura, K., Chen, J., and Fu, P.: Thirteen years of observations on primary sugars and sugar alcohols over remote Chichijima Island in the western North Pacific, Atmos. Chem. Phys., 18, 81-101, https://doi.org/10.5194/acp-1881-2018, 2018.

Wang, G., Kawamura, K., Zhao, X., Li, Q., Dai, Z., and Niu, H.: Identification, abundance, and seasonal variation of anthropogenic organic aerosols from a mega-city in China, Atmos. Environ., 41, 407-416, https://doi.org/10.1016/j.atmosenv.2006.07.033, 2007.

Wang, H., Kawamura, K., and Shooter, D.: Carbonaceous and ionic components in wintertime atmospheric aerosols from two New Zealand cities: implications for solid fuel combustion, Atmos. Environ., 39, 5865-5875, https://doi.org/10.1016/j.atmosenv.2005.06.031, 2005.

Wan, X., Kang, S., Li, Q., Rupakheti, D., Zhang, Q., Guo, J., Chen, P., Tripathee, L., Rupakheti, M., Panday, A. K., Wang, W., Kawamura, K., Gao, S., Wu, G., and Cong, Z.: Organic molecular tracers in the atmospheric aerosols from Lumbini, Nepal, in the northern Indo-Gangetic Plain: influence of biomass burning, Atmos. Chem. Phys., 17, 8867-8885, https://doi.org/10.5194/acp17-8867-2017, 2017.

Wei, L. F., Yue, S. Y., Zhao, W. Y., Yang, W. Y., Zhang, Y. J., Ren, L. J., Han, X. K., Guo, Q. J., Sun, Y. L., Wang, Z. F., and Fu, P. Q.: Stable sulfur isotope ratios and chemical compositions of fine aerosols $\left(\mathrm{PM}_{2.5}\right)$ in Beijing, China, Sci. Total Environ. 633, 1156-1164, https://doi.org/10.1016/j.scitotenv.2018.03.153, 2018.

Xu, S., Ren, L., Lang, Y., Hou, S., Ren, H., Wei, L., Wu, L., Deng, J., Hu, W., Pan, X., Sun, Y., Wang, Z., Su, H., Cheng, Y., and Fu, P.: Molecular markers of biomass burning and primary biological aerosols in urban Beijing: size distribution and seasonal variation, Atmos. Chem. Phys., 20, 3623-3644, https://doi.org/10.5194/acp-20-3623-2020, 2020.

Xu, W. Y., Zhao, C. S., Ran, L., Deng, Z. Z., Liu, P. F., Ma, N., Lin, W. L., Xu, X. B., Yan, P., He, X., Yu, J., Liang, W. D., and Chen, L. L.: Characteristics of pollutants and their correlation to meteorological conditions at a suburban site in the North China Plain, Atmos. Chem. Phys., 11, 4353-4369, https://doi.org/10.5194/acp-11-4353-2011, 2011. 
Yamaguchi, N., Ichijo, T., Sakotani, A., Baba, T., and Nasu, M.: Global dispersion of bacterial cells on Asian dust, Sci. Rep.-UK, 2, 525, https://doi.org/10.1038/srep00525, 2012.

Yan, C., Zheng, M., Sullivan, A. P., Shen, G., Chen, Y., Wang, S., Zhao, B., Cai, S., Desyaterik, Y., Li, X., Zhou, T., Gustafsson, O., and Collett, J. L.: Residential coal combustion as a source of levoglucosan in China, Environ. Sci. Technol., 52, 1665-1674, https://doi.org/10.1021/acs.est.7b05858, 2018.

Yttri, K. E., Dye, C., and Kiss, G.: Ambient aerosol concentrations of sugars and sugar-alcohols at four different sites in Norway, Atmos. Chem. Phys., 7, 4267-4279, https://doi.org/10.5194/acp7-4267-2007, 2007.

Yu, L., Wang, G., Zhang, R., Zhang, L., Song, Y., Wu, B. B., Li, X. F., An, K., and Chu, J. H.: Characterization and source apportionment of $\mathrm{PM}_{2.5}$ in an urban environment in Beijing, Aerosol Air Qual. Res., 13, 574-583, https://doi.org/10.4209/aaqr.2012.07.0192, 2013.
Zhang, Y. X., Shao, M., Zhang, Y. H., Zeng, L. M., He, L. Y., Zhu, B., Wei, Y. J., and Zhu, X. L.: Source profiles of particulate organic matters emitted from cereal straw burnings, J. Environ. Sci.-China, 19, 167-175, https://doi.org/10.1016/S10010742(07)60027-8, 2007.

Zhou, L., Kim, E., Hopke, P. K., Stanier, C. O., and Pandis, S.: Advanced factor analysis on Pittsburgh particle size-distribution data special issue of aerosol science and technology on findings from the fine particulate matter supersites program, Aerosol Sci. Technol., 38, 118-132, https://doi.org/10.1080/02786820390229589, 2004.

Zhu, C., Kawamura, K., Fukuda, Y., Mochida, M., and Iwamoto, Y.: Fungal spores overwhelm biogenic organic aerosols in a midlatitudinal forest, Atmos. Chem. Phys., 16, 7497-7506, https://doi.org/10.5194/acp-16-7497-2016, 2016. 